Original Article

\title{
Combining ability analysis in bitter gourd (Momordica charantia L.) for potential quality improvement
}

\author{
Análise de capacidade de combinação em cabaça-amarga (Momordica charantia L.) \\ para melhoria potencial da qualidade
}

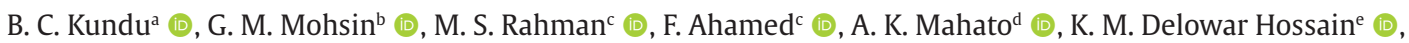
M. B. Jalloh ${ }^{\mathrm{f}}$ () and Md. Amirul Alam ${ }^{\mathrm{g} *}$ (1)

aBangladesh Agricultural Research Institute - BARI, Tuber Crops Research Institute, Joydebpur, Gazipur, Bangladesh

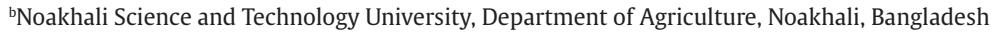

'Lal Teer Seed Limited, R\&D, Bashon, Gazipur, Bangladesh

dSher-e-Bangla Agricultural University, Department of Horticulture, Dhaka, Bangladesh

eJashore University of Science and Technology, Department of Environmental Science and Technology, Jashore, Bangladesh

fUniversiti Malaysia Sabah, Faculty of Sustainable Agriculture, Crop Production Program, Sandakan, Sabah, Malaysia

gUniversiti Malaysia Sabah, Faculty of Sustainable Agriculture, Horticulture and Landscaping Program, Sandakan, Sabah, Malaysia

\begin{abstract}
Combining ability analysis provides useful information for the selection of parents, also information regarding the nature and magnitude of involved gene actions. Crops improvement involves strategies for enhancing yield potentiality and quality components. Targeting the improvement of respective characters in bitter gourd, combining ability and genetic parameters for 19 characters were estimated from a $6 \times 6$ full diallel analysis technique. The results revealed that the variances due to general combining ability (GCA) and specific combining ability (SCA) were highly significant for most of the important characters. It indicated the importance of both additive and non-additive gene actions. GCA variances were higher in magnitude than SCA variances for all the characters studied indicating the predominance of the additive gene effects in their inheritance. The parent $\mathrm{P}_{2}$ (BG 009) appeared as the best general combiner for earliness; $\mathrm{P}_{1}$ (BG 006) for number of fruits, average single fruit weight and fruit yield; $\mathrm{P}_{4}$ (BG 027) for node number of first female flower and days to seed fruit maturity; $\mathrm{P}_{3}$ (BG 011) for fruit length and thickness of the fruit flesh; $\mathrm{P}_{5}$ (BG 033) for 100-seed weight; and $\mathrm{P}_{6}$ for number of nodes per main vine. The SCA effect as well as reciprocal effect was also significant for most of the important characters in different crosses.
\end{abstract}

Keywords: bitter gourd (Momordica charanta L.), genetic parameters, diallel, GCA, SCA.

\begin{abstract}
Resumo
A análise da capacidade de combinação fornece informações úteis para a seleção dos pais, também informações sobre a natureza e a magnitude das ações dos genes envolvidos. A melhoria das safras envolve estratégias para aumentar a potencialidade da produção e os componentes de qualidade. Visando ao aprimoramento dos respectivos caracteres em cabaça-amarga, capacidade de combinação e parâmetros genéticos para 19 caracteres, foram estimados a partir de uma técnica de análise dialélica completa $6 \times 6$. Os resultados revelaram que as variâncias, devido à capacidade geral de combinação (GCA) e capacidade específica de combinação (SCA), foram altamente significativas para a maioria dos caracteres importantes. Indicou a importância das ações gênicas aditivas e não aditivas. As variâncias GCA foram maiores em magnitude do que as variâncias SCA para todos os caracteres estudados, indicando a predominância dos efeitos do gene aditivo em sua herança. O pai $P_{2}$ (BG 009) apareceu como o melhor combinador geral para o início; $\mathrm{P}_{1}$ (BG 006) para número de frutos, peso médio de um único fruto e produção de frutos; $\mathrm{P}_{4}$ (BG 027) para número de nó da primeira flor fêmea e dias para a maturidade do fruto da semente; $\mathrm{P}_{3}$ (BG 011) para comprimento do fruto e espessura da polpa do fruto; $\mathrm{P}_{5}$ (BG 033) para peso de 100 sementes; e $\mathrm{P}_{6}$ para 0 número de nós por videira principal. O efeito SCA, bem como o efeito recíproco, também foi significativo para a maioria dos personagens importantes em cruzamentos diferentes.
\end{abstract}

Palavras-chave: cabaça-amarga (Momordica charantia L.), parâmetros genéticos, dialelo, GCA, SCA.

*e-mail: amirulalam@ums.edu.my

Received: August 23, 2021 - Accepted: October 8, 2021 


\section{Introduction}

Bitter gourd (Momordica charantia L.) locally known as Karala/Uchha is an important vegetable and belongs to the family Cucurbitaceae. Compared to other cucurbits, bitter gourd has relatively high nutritional value in respect of iron and ascorbic acid contents with antidiabetic and anti-obesity properties. It is a rich source of antioxidants, flaviooids and other polyphenol compounds (Alam et al., 2015). Rose et al. (2014) reported that 100 grams of the fruit contain about $92 \mathrm{~mL}$ water, 25 calories, $1.2 \mathrm{~g}$ protein, $0.2 \mathrm{~g}$ fat, $5 \mathrm{~g}$ carbohydrate, $1.0 \mathrm{~g}$ fiber, $13 \mathrm{mg}$ calcium, 32 mg phosphorus, $0.2 \mathrm{mg}$ iron, $0.02 \mathrm{mg}$ thiamine and 0.07 $\mathrm{mg}$ riboflavin. The per capita consumption of vegetable in Bangladesh is about $50 \mathrm{~g}$ per day, which is the lowest among the countries of South and South East Asia. WHO/ FAO recommends intake of a minimum of 400 grams or five servings of fruits and vegetables per day for the prevention of chronic diseases such as heart diseases, cancer, diabetes, and obesity. There is a big gap between the demand and supply of vegetables in Bangladesh. Therefore, from nutrient and health benefit considerations, improvement of crop yield and production of this vegetable crop is desirable and important to mitigate the future demand.

A sound-breeding program provides the opportunity to produce high yielding varieties of a crop with superior quality. However, the development of a meaningful breeding program needs information on the nature of gene actions controlling the economic characters and other characters of importance. Knowledge of genetic architecture of the characters under improvement is essential for adopting appropriate breeding procedure. Such knowledge leads the plant breeder to develop new commercial varieties of the crop. Begna (2021) stressed that information on variation attributable to genetic differences and also on the relationship among various quantitative traits is fundamentally significant in crop improvement program. In a heterosis breeding program, the breeder is often confronted with problems in choosing desirable parents. The common approach of selecting parents on the basis of per se performance does not necessarily lead to the best result in hybridization program (Labroo et al., 2021). Combining ability studies are more reliable as they provide useful information for the selection of parents in terms of performance of the hybrids and elucidate the nature and magnitude of various types of gene actions involved in the expression of quantitative traits. Diallel cross analysis provides the estimates of genetic parameters regarding combining ability as well as a rapid overall picture of the dominance relationship of the parents studied using the first filial generation $\left(\mathrm{F}_{1}\right)$ with or without reciprocals. Diallel analysis involving parents give the additional information as presence or absence of epistasis, average degree of dominance, distribution of dominant and recessive genes in the parents (Zongo et al., 2019). Bitter gourd being a monoecious crop, there exists bright scope for exploitation of heterosis. The heterozygous nature of bitter gourd and virtually the obligatory out crossing breeding system of bitter gourd opens the scope of development of open-pollinated as well as hybrid variety. A number of superior hybrids of bitter gourd have been developed for cultivation in different countries. Quamruzzaman et al. (2020) observed a high level of heterosis (86.1\%) in full diallel cross among 11 diverse parents in bottle gourd. Behera et al. (2020) reported that $F_{1}$ hybrid was derived from the crosses between pure-line of bitter gourd having good specific combiners for yield and its components. Valyaie et al. (2021) reported that heterosis was obtained in seed quality character and yield. Mishra and Singh (2018) also reported that superior performance of $F_{1}$ hybrids showing high SCA was largely due to epistatic interaction. In Bangladesh, very limited information is available for determining nature of gene effects and inheritance of yield and yield contributing attributes in bitter gourd. In this regard the present experiment was undertaken to reveal the general and specific combining ability in bitter gourd for the development of high yielding variety.

\section{Materials and Methods}

\subsection{Plant materials}

The experiment was conducted with six diverse genotypes of bitter gourd, namely BG 006, BG 009, BG 011, BG 027, BG 033 and BG 036 were selected as parents (designated respectively as $\mathrm{P}_{1}, \mathrm{P}_{2}, \mathrm{P}_{3}, \mathrm{P}_{4}, \mathrm{P}_{5}$, and $\mathrm{P}_{6}$ ) based on their performances and some qualitative characters. The six parents were grown and crossed in all possible combinations. The parents were grown along with their $\mathrm{F}_{1}$ 's population.

\subsection{Experimental design and layout}

The field experiment was arranged in a randomized complete block design with three replications. There were three plants per replication. The spacing adopted was (2.0 $x$ 1.0) $\mathrm{m}^{2}$. A good drainage system was maintained for draining out of rain water from the field. For better growth and development of the plants, recommended balanced combination of manures (well decomposed cow dung $15000 \mathrm{~kg} / \mathrm{ha}$ ) and fertilizers (Urea $175 \mathrm{~kg} / \mathrm{ha}$; TSP $175 \mathrm{~kg} /$ ha; MP 150 kg/ha; Gypsum 100 kg/ha; Zinc oxide $12 \mathrm{~kg} /$ ha and Borax $7 \mathrm{~kg} / \mathrm{ha}$ ) were applied (Nasreen et al., 2013).

\subsection{Data collection for quantitative characters}

Days to first male flower opening, node number of first male flower, days to first female flower opening, node number of first female flower, main vine length $(\mathrm{cm})$, numbers of primary branches per vine, numbers of nodes per main vine, number of fruits per vine, average single fruit weight $(\mathrm{g})$, fruit yield per vine $(\mathrm{kg})$, fruit length $(\mathrm{cm})$, fruit diameter $(\mathrm{cm})$, thickness of the fruit flesh $(\mathrm{mm})$, thickness of the rind ( $\mathrm{mm}$ ), days to green fruit maturity, days to seed fruit maturity, number of seeds per fruit, seed weight per fruit $(\mathrm{g})$, and 100-seed weight $(\mathrm{g})$ were recorded accordingly. For every parameters, data were collected three times and average was calculated.

\subsection{Analysis of variance (ANOVA)}

All the quantitative data taken were subjected to ANOVA. The total variances of each character were partitioned in 
two block, genotype and error differences. The differences within the classes of effects were tested by F-test.

\subsection{Combining ability}

The statistical analysis of data for $6 \times 6$ diallel crosses including reciprocals were done as quoted in Fasahat et al. (2016). The diallel progenies $\left(n^{2}=36\right)$ were portioned into parents $(P)$, crosses $\left(F_{1}\right)$, parent vs crosses $\left(P\right.$ vs. $\left.F_{1}\right)$, direct crosses (f), reciprocal crosses (l) and direct vs. reciprocal items. The parents, crosses, direct cross, reciprocal crosses items tested the significant differences among the parents, crosses, direct crosses and reciprocal crosses, respectively. $\mathrm{P}$ vs. $\mathrm{F}_{1}$ item indicated overall heterosis for the respective character. While f vs. 1 item indicates presence of reciprocal differences, thus necessitates computation of reciprocal differences. For the genetic analysis of Diallel population, data were subjected to Griffing's approaches. An understanding of the general and specific combining ability and the genetic system controlling important traits of bitter gourd was thus attempted.

\subsubsection{Griffing's approach (Combining ability analysis)}

Griffing's (1956) method 1, Model 2 (Random effects model) was used for combining ability analysis for each of the trait. In model 2, random samples drawn as parents from some populations are dealt with and inferences do not apply to the sample but to the parental populations from which samples are drawn.

The mathematical model for the combining ability analysis in model 2, method 1 is assumed to be (Equation 1 ):

$$
\mathrm{Xij}=\mu+\mathrm{gi}+\mathrm{gj}+\mathrm{Sij}+\mathrm{rij}+\frac{1}{\mathrm{bc}} \sum_{\mathrm{k}} \sum_{\mathrm{l}} \mathrm{eijkl}
$$

Where,

$\mathrm{i}, \mathrm{j}=1 \ldots \ldots \ldots \ldots \ldots . . . \mathrm{P}$

$\mathrm{k}=1 \ldots \ldots \ldots \ldots \ldots \ldots \ldots$

$1=1 \ldots \ldots \ldots \ldots \ldots \ldots . . . \mathrm{C}$

$\mathrm{p}=$ number of parents

$\mathrm{b}=$ number of blocks

$\mathrm{c}=$ number of observation in each plot

$\mathrm{Xij}=$ mean of $\mathrm{Xij}$ the genotypes over $\mathrm{k}$ and $\mathrm{l}$

$\mu=$ population mean

gi, gj = gca effects

Sij = specific combining ability effect i.e. sca effects

$r_{i j}=$ reciprocal effect

$\mathrm{e}_{\mathrm{ijkl}}=$ environmental effect particular to the ijklth individual observation

The restriction imposed are- $\Sigma=0$ and $\Sigma(\mathrm{Sij}+\mathrm{Sii})=0$ (for each I).

\section{Results and Discussion}

The analysis of variance (ANOVA) showed highly significant differences among parents and crosses for all the characters studied (Table $1 \mathrm{a}, 1 \mathrm{~b}, 1 \mathrm{c}, 1 \mathrm{~d}$ ). The significant mean square due to general combining ability (GCA) and specific combining ability (SCA) for all the characters indicated that both additive and non-additive gene actions played dominant role for the expression of these characters. The higher magnitude of SCA variance than that of GCA variance for only one character out of nineteen characters studied indicated the predominance of the non-additive gene effects for that character. Mean square of reciprocal effect of 11 characters was higher than the SCA, which indicated that reciprocal effect also exists in bitter gourd. Devi et al. (2017a) found both additive and non-additive gene action in snake gourd. Jasim and Esho (2021) reported that additive variance was responsible for vine length whereas, non-additive for yield in summer squash. Similar results were also found in eggplant (Devmore et al., 2016), in bitter gourd (Talukder et al., 2018), in cucumber (Golabadi et al., 2017), and in bottle gourd Quamruzzaman et al. (2020) found non-additive gene effects for first female flowering node as well as female flower number per stem, branches per plant in ridge gourd. Quamruzzaman et al. (2009) studied $45 \mathrm{~F}_{1}$ crosses of 10 parents of bottle gourd and found the best $\mathrm{F}_{1}$ hybrid ( $\mathrm{S} 54$ x S 52 -7) attributed higher estimates of fruits per plants, fruits weight and fruit size. Kaniti (2016) recorded highly significant variations for genotypes, parents and hybrids in six parents' diallel cross of bitter gourd for yield per plant. He reported highly significant variations for both general and specific combining ability and high GCA:SCA. Shukla et al. (2014a) studied ll parent diallel in bitter gourd and observed that GCA and SCA variances were significant for all 13 characters they studied. They observed that this variance due to GCA were consistently greater than the SCA variances for all the characters. Singh et al. (2013) found that the GCA and SCA variances were highly significant in a $10 \times 10$ diallel in bitter gourd for days to first female flower opening during three seasons.

The GCA component is primarily a function of the additive genetic variance. GCA and SCA variance with each parent play significant role in parent selection. A parent with higher positive significant GCA effects is considered as a good general combiner. The magnitude and direction of the significant effects for the eight parents in this study provide meaningful comparisons and would give indications to the future breeding program.

The results of GCA effect for 19 different characters of six parental lines are presented in the Table 2a, 2b and 2c. Negative GCA effect is preferable for days to flowering as it indicates the earliness of the parents. Highly significant $\left(2.33^{* *}\right)$ and the highest positive GCA effect (49.81) was recorded for $\mathrm{P}_{3}$ for days to first male flower opening (Table $2 \mathrm{a}$ ). The parent $\mathrm{P}_{6}$ showed low but positive significant effect. On the other hand, $\mathrm{P} 1$ and $\mathrm{P}_{2}$ showed highly significant and negative GCA effect $\left(-1.51^{* *}\right.$ and $1.73^{* *}$ ) followed by $\mathrm{P}_{1}$ and $\mathrm{P}_{4}$. Hence, the parent $\mathrm{P}_{1}$ and $\mathrm{P}_{2}$ were the best general combiner for promoting early flowering in bitter gourd.

Regarding the node number for bearing the first male flower, parent $\mathrm{P}_{6}$ had highly significant $\left(1.19^{* *}\right)$ and positive GCA effect (21.16), while parent $P_{1}$ had highly significant $\left(-1.23^{* *}\right)$ but negative GCA effect (18.74). GCA effect of parents $\mathrm{P}_{2}, \mathrm{P}_{3}$ and $\mathrm{P}_{4}$ for this parameter was non-significant. Hence, the parent $P_{1}$ was the best general combiner for 
Table 1a. Analysis of variance for combining ability of days to flower and growth character in bitter gourd.

\begin{tabular}{ccccccccc}
\hline & \multicolumn{7}{c}{ Character (Mean sum of square) } \\
\cline { 3 - 9 } $\begin{array}{c}\text { Source of } \\
\text { variation }\end{array}$ & d.f & $\begin{array}{c}\text { Days to } \\
\text { first } \\
\text { male } \\
\text { flower } \\
\text { opening }\end{array}$ & $\begin{array}{c}\text { Node } \\
\text { number of } \\
\text { first male } \\
\text { flower }\end{array}$ & $\begin{array}{c}\text { Days } \\
\text { to first } \\
\text { female } \\
\text { flower } \\
\text { opening }\end{array}$ & $\begin{array}{c}\text { Node } \\
\text { number } \\
\text { of first } \\
\text { female } \\
\text { flower }\end{array}$ & $\begin{array}{c}\text { Main vine } \\
\text { length } \\
\text { (m) }\end{array}$ & $\begin{array}{c}\text { No. of } \\
\text { primary } \\
\text { branches } \\
\text { per vine }\end{array}$ & $\begin{array}{c}\text { No. of } \\
\text { nodes per } \\
\text { main vine } \\
\text { (no.) }\end{array}$ \\
\hline Block & 2 & $38.19^{* *}$ & $63.35^{* *}$ & $97.69^{* *}$ & $13.17^{* *}$ & $2.16^{* *}$ & $0.96^{* *}$ & $1135.39^{* *}$ \\
Crosses & 35 & $35.79^{* *}$ & $22.78^{* *}$ & $46.04^{* *}$ & $35.67^{* *}$ & $0.74^{* *}$ & $1.44^{* *}$ & $151.80^{* *}$ \\
GCA & 5 & $94.09^{* *}$ & $26.79^{* *}$ & $96.54^{* *}$ & $81.45^{* *}$ & $1.70^{* *}$ & $5.03^{* *}$ & $428.54^{* *}$ \\
SCA & 15 & $22.44^{* *}$ & $31.60^{* *}$ & $27.33^{* *}$ & $33.89^{* *}$ & $0.51^{* *}$ & $0.97^{* *}$ & $99.61^{* *}$ \\
Reciprocal & 15 & $29.72^{* *}$ & $12.63^{* *}$ & $47.91^{* *}$ & $22.20^{* *}$ & $0.65^{* *}$ & $0.72^{* *}$ & $111.75^{* *}$ \\
Error & 70 & 2.47 & 3.5 & 8.16 & 4.47 & 0.18 & 0.23 & 44.20 \\
SCA/GCA & 1 & 0.24 & 1.18 & 0.28 & 0.42 & 0.30 & 0.19 & 0.23 \\
Rec/GCA & 1 & 0.32 & 0.47 & 0.50 & 0.27 & 0.38 & 0.14 & 0.26 \\
\hline
\end{tabular}

${ }^{* *}$ Significant at $1 \%$ level of probability. d.f. - degrees of freedom.

Table 1b. Analysis of variance for combining ability of days to flower and growth character in bitter gourd.

\begin{tabular}{|c|c|c|c|c|c|c|c|c|}
\hline \multirow[b]{2}{*}{$\begin{array}{l}\text { Source of } \\
\text { variation }\end{array}$} & \multirow[b]{2}{*}{ d.f } & \multicolumn{7}{|c|}{ Character (Mean sum of square) } \\
\hline & & $\begin{array}{c}\text { Days to } \\
\text { first } \\
\text { male } \\
\text { flower } \\
\text { opening }\end{array}$ & $\begin{array}{c}\text { Node } \\
\text { number of } \\
\text { first male } \\
\text { flower }\end{array}$ & $\begin{array}{c}\text { Days } \\
\text { to first } \\
\text { female } \\
\text { flower } \\
\text { opening }\end{array}$ & $\begin{array}{c}\text { Node } \\
\text { number } \\
\text { of first } \\
\text { female } \\
\text { flower }\end{array}$ & $\begin{array}{l}\text { Main vine } \\
\text { length } \\
\text { (m) }\end{array}$ & $\begin{array}{c}\text { No. of } \\
\text { primary } \\
\text { branches } \\
\text { per vine }\end{array}$ & $\begin{array}{c}\text { No. of } \\
\text { nodes per } \\
\text { main vine } \\
\text { (no.) }\end{array}$ \\
\hline Block & 2 & $38.19^{* *}$ & $63.35^{* *}$ & $97.69^{* *}$ & $13.17^{* *}$ & $2.16^{* *}$ & $0.96^{* *}$ & $1135.39^{* *}$ \\
\hline Crosses & 35 & $35.79^{* *}$ & $22.78^{* *}$ & $46.04^{* *}$ & $35.67^{* *}$ & $0.74^{* *}$ & $1.44^{* *}$ & $151.80^{* *}$ \\
\hline GCA & 5 & $94.09^{* *}$ & $26.79^{* *}$ & $96.54^{* *}$ & $81.45^{* *}$ & $1.70^{* *}$ & $5.03^{* *}$ & $428.54^{* *}$ \\
\hline SCA & 15 & $22.44^{* *}$ & $31.60^{* *}$ & $27.33^{* *}$ & $33.89^{* *}$ & $0.51^{* *}$ & $0.97^{* *}$ & $99.61^{* *}$ \\
\hline Reciprocal & 15 & $29.72^{* *}$ & $12.63^{* *}$ & $47.91^{* *}$ & $22.20^{* *}$ & $0.65^{* *}$ & $0.72^{* *}$ & $111.75^{* *}$ \\
\hline Error & 70 & 2.47 & 3.5 & 8.16 & 4.47 & 0.18 & 0.23 & 44.20 \\
\hline SCA/GCA & 1 & 0.24 & 1.18 & 0.28 & 0.42 & 0.30 & 0.19 & 0.23 \\
\hline $\mathrm{Rec} / \mathrm{GCA}$ & 1 & 0.32 & 0.47 & 0.50 & 0.27 & 0.38 & 0.14 & 0.26 \\
\hline
\end{tabular}

${ }^{* *}$ Significant at $1 \%$ level of probability. d.f. - degrees of freedom

Table 1c. Analysis of variance for combining ability of fruit yield and fruit characters in bitter gourd.

\begin{tabular}{|c|c|c|c|c|c|c|c|c|}
\hline \multirow[b]{2}{*}{$\begin{array}{l}\text { Source of } \\
\text { variation }\end{array}$} & \multirow[b]{2}{*}{ d.f } & \multicolumn{7}{|c|}{ Character (Mean sum of square) } \\
\hline & & $\begin{array}{c}\text { Number } \\
\text { of fruits } \\
\text { per vine } \\
\text { (no.) }\end{array}$ & $\begin{array}{l}\text { Av. Single } \\
\text { fruit } \\
\text { weight (g) }\end{array}$ & $\begin{array}{l}\text { Fruit yield } \\
\text { per vine } \\
\text { (kg) }\end{array}$ & $\begin{array}{c}\text { Fruit } \\
\text { length } \\
(\mathrm{cm})\end{array}$ & $\begin{array}{c}\text { Fruit } \\
\text { diameter } \\
(\mathrm{cm})\end{array}$ & $\begin{array}{c}\text { Thickness } \\
\text { of fruit } \\
\text { flesh } \\
(\mathbf{m m})\end{array}$ & $\begin{array}{l}\text { Thickness } \\
\text { of fruit } \\
\text { rind (mm) }\end{array}$ \\
\hline Block & 2 & $22.54^{* *}$ & $521.45^{* *}$ & $0.03^{* *}$ & $15.87^{* *}$ & $0.60^{* *}$ & $12.45^{* *}$ & $1.34^{* *}$ \\
\hline Crosses & 35 & $40.9^{* *}$ & $1843.41^{* *}$ & $0.25^{* *}$ & $17.25^{* *}$ & $0.41^{* *}$ & $14.52^{* *}$ & $0.79^{* *}$ \\
\hline GCA & 5 & $75.68^{* *}$ & $7019.63^{* *}$ & $0.78^{* *}$ & $78.51^{* *}$ & $1.08^{* *}$ & $27.31^{* *}$ & $1.96^{* *}$ \\
\hline SCA & 15 & $31.23^{* *}$ & $1168.61^{* *}$ & $0.16^{* *}$ & $6.43^{* *}$ & $0.18^{* *}$ & $12.60^{* *}$ & $0.59^{* *}$ \\
\hline Reciprocal & 15 & $37.80^{* *}$ & $792.81^{* *}$ & $0.16^{* *}$ & $7.66^{* *}$ & $0.41^{* *}$ & $12.19^{* *}$ & $0.59^{* *}$ \\
\hline Error & 70 & 2.97 & 62.03 & 0.01 & 2.87 & 0.11 & 3.76 & 0.35 \\
\hline SCA/GCA & 1 & 0.41 & 0.17 & 0.21 & 0.08 & 0.17 & 0.46 & 0.30 \\
\hline $\mathrm{Rec} / \mathrm{GCA}$ & 1 & 0.50 & 0.11 & 0.21 & 0.10 & 0.38 & 0.45 & 0.30 \\
\hline
\end{tabular}

${ }^{* *}$ Significant at $1 \%$ level of probability. d.f. - degrees of freedom 
using in crosses to promote the lower node number to bear male flower (Table 2a).

The parent $P_{5}$ provided highly significant $\left(2.16^{* *}\right)$ positive GCA effect for days to bear first female flower (52.29 days) followed by $\mathrm{P}_{3}$ and hence, these two parents were undesirable general combiners to promote the earliness in bitter gourd. On the other hand, $\mathrm{P}_{2}$ revealed highly significant $\left(-1.73^{* *}\right)$ and negative GCA effect and lower parental mean (48.40 days) for this trait. Thus $\mathrm{P}_{2}$ can be selected as the best general combiner for enhancing early fruiting in this crop (Table 2a).

Highly significant $\left(1.84^{* *}\right)$ positive GCA effect was provided by $\mathrm{P}_{5}$ for node number for bearing the first female flower (29.97). The parents $P_{1}$ and $P_{2}$ showed low and positive non-significant effects. On the other hand, $\mathrm{P}_{4}$ showed highly significant $\left(-2.37^{* *}\right)$ but negative significant
GCA effects (25.76). Hence, the parent $\mathrm{P}_{4}$ was the best general combiner for promoting lower node number for bearing the first female flower (Table 2a).

The parent $\mathrm{P}_{6}$ projected significant $\left(1.15^{*}\right)$ highest positive GCA effect $(29.28 \mathrm{~m}$ ) for main vine length, while the parent $\mathrm{P}_{1}$ showed low but positive non-significant GCA effects for this trait. The parent $\mathrm{P}_{4}$ showed highly significant $\left(-2.37^{* *}\right)$ and negative GCA effects $(25.76 \mathrm{~m})$ followed by $\mathrm{P}_{3}\left(-0.98^{*}\right)$. Thus, $\mathrm{P}_{6}$ was found to be good for using in the breeding programs for long vine and $\mathrm{P}_{4}$ for short vine (Table 2a).

The parent $\mathrm{P}_{6}$ was identified with highly significant $\left(0.69^{* *}\right)$ and the highest positive GCA effects for number of primary branches (5.69) per vine (Table 2a). While $\mathrm{P}_{2}$ was identified with highly significant $\left(-0.32^{* *}\right)$ and the lowest negative GCA effects for number of primary branches

Table 1d. Analysis of variance for combining ability of days to maturity and seed characters in bitter gourd.

\begin{tabular}{|c|c|c|c|c|c|c|}
\hline \multirow{2}{*}{$\begin{array}{l}\text { Source of } \\
\text { variation }\end{array}$} & \multirow[b]{2}{*}{ d.f } & \multicolumn{5}{|c|}{ Character (Mean sum of square) } \\
\hline & & $\begin{array}{l}\text { Days to green } \\
\text { fruit maturity }\end{array}$ & $\begin{array}{l}\text { Days to seed } \\
\text { fruit maturity }\end{array}$ & $\begin{array}{c}\text { Number of } \\
\text { seed per fruit }\end{array}$ & $\begin{array}{l}\text { Seed weight } \\
\text { per fruit (g) }\end{array}$ & $\begin{array}{c}100 \text { seed } \\
\text { weight }(g)\end{array}$ \\
\hline Block & 2 & $7.01^{* *}$ & $4.86^{* *}$ & $0.11^{* *}$ & $0.34^{* *}$ & $4.72^{* *}$ \\
\hline Crosses & 35 & $6.65^{* *}$ & $3.75^{* *}$ & $58.38^{* *}$ & $1.18^{* *}$ & $11.25^{* *}$ \\
\hline GCA & 5 & $12.88^{* *}$ & $4.94^{* *}$ & $133.76^{* *}$ & $1.28^{* *}$ & $25.9^{* *}$ \\
\hline SCA & 15 & $5.64^{* *}$ & $2.37^{* *}$ & $30.56^{* *}$ & $0.86^{* *}$ & $7.76^{* *}$ \\
\hline Reciprocal & 15 & $5.58^{* *}$ & $4.73^{* *}$ & $61.09^{* *}$ & $1.47^{* *}$ & $9.85^{* *}$ \\
\hline Error & 70 & 2.29 & 1.39 & 1.82 & 0.23 & 1.21 \\
\hline SCA/GCA & 1 & 0.44 & 0.48 & 0.23 & 0.67 & 0.30 \\
\hline $\operatorname{Rec} / G C A$ & 1 & 0.43 & 0.96 & 0.46 & 1.15 & 0.38 \\
\hline
\end{tabular}

${ }^{* *}$ Significant at $1 \%$ level of probability. d.f. - degrees of freedom

Table 2a. General combining ability effects for days to flower and growth character in six bitter gourd genotypes.

\begin{tabular}{|c|c|c|c|c|c|c|c|}
\hline \multirow[b]{2}{*}{ Parents } & \multicolumn{7}{|c|}{ Characters } \\
\hline & $\begin{array}{l}\text { Days to first } \\
\text { male flower } \\
\text { opening }\end{array}$ & $\begin{array}{c}\text { Node } \\
\text { number of } \\
\text { first male } \\
\text { flower }\end{array}$ & $\begin{array}{c}\text { Days to } \\
\text { first female } \\
\text { flower } \\
\text { opening }\end{array}$ & $\begin{array}{c}\text { Node } \\
\text { number of } \\
\text { first female } \\
\text { flower }\end{array}$ & $\begin{array}{l}\text { Main vine } \\
\text { length } \\
(\mathbf{m})\end{array}$ & $\begin{array}{c}\text { No. of } \\
\text { primary } \\
\text { branches } \\
\text { per vine }\end{array}$ & $\begin{array}{c}\text { No. of nodes } \\
\text { per main } \\
\text { vine (no.) }\end{array}$ \\
\hline$P_{1}(B G 006)$ & $\begin{array}{l}-1.51^{* *} \\
(45.97)\end{array}$ & $\begin{array}{l}-1.23^{* *} \\
(18.74)\end{array}$ & $\begin{array}{c}-1.42^{*} \\
(48.71)\end{array}$ & $\begin{array}{c}0.14 \\
(28.27)\end{array}$ & $\begin{array}{c}0.14 \\
(28.27)\end{array}$ & $\begin{array}{c}-0.17 \\
(4.74)\end{array}$ & $\begin{array}{c}-0.63 \\
(76.50)\end{array}$ \\
\hline$P_{2}(B G 009)$ & $\begin{array}{l}-1.73^{* *} \\
(45.75)\end{array}$ & $\begin{array}{c}0.13 \\
(20.10)\end{array}$ & $\begin{array}{l}-1.73^{* *} \\
(48.40)\end{array}$ & $\begin{array}{c}0.21 \\
(28.37)\end{array}$ & $\begin{array}{c}0.21 \\
(28.37)\end{array}$ & $\begin{array}{c}-0.32^{* *} \\
(4.59)\end{array}$ & $\begin{array}{c}-1.78 \\
(74.08)\end{array}$ \\
\hline $\mathrm{P}_{3}(\mathrm{BG} 011)$ & $\begin{array}{c}2.33^{*} \\
(49.81)\end{array}$ & $\begin{array}{c}0.04 \\
(20.01)\end{array}$ & $\begin{array}{c}1.19^{*} \\
(51.32)\end{array}$ & $\begin{array}{l}-0.98^{*} \\
(27.15)\end{array}$ & $\begin{array}{l}-0.98^{*} \\
(27.15)\end{array}$ & $\begin{array}{l}-0.21^{*} \\
(4.70)\end{array}$ & $\begin{array}{c}-0.60 \\
(75.28)\end{array}$ \\
\hline $\mathrm{P}_{4}$ (BG 027 & $\begin{array}{c}-0.87^{*} \\
(46.61)\end{array}$ & $\begin{array}{c}-0.68 \\
(19.29)\end{array}$ & $\begin{array}{c}-1.18^{*} \\
(48.95)\end{array}$ & $\begin{array}{l}-2.37^{* *} \\
(25.76)\end{array}$ & $\begin{array}{l}-2.37^{* *} \\
(25.76)\end{array}$ & $\begin{array}{c}-0.16 \\
(4.74)\end{array}$ & $\begin{array}{l}-4.31^{* *} \\
(71.57)\end{array}$ \\
\hline$P_{5}(B G 033$ & $\begin{array}{c}1.01^{* *} \\
(48.49)\end{array}$ & $\begin{array}{c}0.56 \\
(20.54)\end{array}$ & $\begin{array}{c}2.16^{* *} \\
(52.29)\end{array}$ & $\begin{array}{c}1.84^{* *} \\
(29.97)\end{array}$ & $\begin{array}{c}1.84^{* *} \\
(29.97)\end{array}$ & $\begin{array}{c}0.17 \\
(5.07)\end{array}$ & $\begin{array}{c}-0.02 \\
(75.86)\end{array}$ \\
\hline$P_{6}(B G 036)$ & $\begin{array}{c}0.77 \\
(48.25)\end{array}$ & $\begin{array}{c}1.19^{* *} \\
(21.16)\end{array}$ & $\begin{array}{c}0.98 \\
(51.10)\end{array}$ & $\begin{array}{c}1.15^{*} \\
(29.28)\end{array}$ & $\begin{array}{c}1.15^{*} \\
(29.28)\end{array}$ & $\begin{array}{l}0.69^{* *} \\
(5.59)\end{array}$ & $\begin{array}{c}6.08^{* *} \\
(81.96)\end{array}$ \\
\hline SE gi & 0.24 & 0.29 & 0.43 & 0.32 & 0.32 & 0.07 & 1.01 \\
\hline SE (gi-gj) & 0.37 & 0.44 & 0.67 & 0.50 & 0.50 & 0.11 & 1.57 \\
\hline
\end{tabular}

Figures in the parenthesis are the mean values. ${ }^{*}$ Significant at $5 \%$ level of probability; ${ }^{* *}$ Significant at $1 \%$ level of probability. Non staric means non-significant up to $5 \%$ level of probability. 
(4.59) per vine, followed by $P_{3}$. The GCA effects for other parents were not significant. Therefore, $\mathrm{P}_{6}$ would be a better selection in breeding programs for greater number of primary branches per vine and $\mathrm{P}_{2}$ would be a better selection for lesser number of primary branches per vine.

The parent $\mathrm{P}_{6}$ exhibited highly significant $\left(6.08^{* *}\right)$ and positive and $\mathrm{P}_{5}$ showed low and positive insignificant GCA effects for number of nodes per main vine with mean values of 81.96 and 75.86, respectively. The parent $\mathrm{P}_{4}$ showed highly significant $\left(-4.31^{* *}\right)$ and the lowest negative GCA effect. Thus, $\mathrm{P}_{6}$ was found to be good for using in breeding programs for more nodes on main vine (Table $2 \mathrm{a}$ ).

For numbers of fruits per vine P1 (12.94) exhibited highly significant and positive GCA effects (1.76**) followed by $\mathrm{P}_{4}$ $\left(1.40^{* *}\right)$ and $\mathrm{P}_{2}\left(0.96^{*}\right)$, respectively (Table $2 \mathrm{~b}$ ). The lowest significant GCA effects was observed for parent $\mathrm{P}_{2}\left(0.69^{*}\right)$. Highly significant but negative GCA effects $\left(-1.49^{* *}\right)$ was recorded in parent $\mathrm{P}_{3}$ followed by $\mathrm{P}_{6}$ and $\mathrm{P}_{5}$. Considering these characters, three parents showed positive and other three parents showed negative GCA effects. Thus, $\mathrm{P}_{1}$ was the best general combiner to use in hybridization program to improve number of fruits per plant in bitter gourd since it had higher mean value along with significant and higher GCA. Parent $\mathrm{P}_{4}$ may be considered as the second parent for this trait (Table 2b).The estimate of GCA effects for average single fruit weight $(107 \mathrm{~g})$ showed that parent $\mathrm{P}_{1}$ had highly significant highest positive value $\left(17.18^{* *}\right)$ followed by $\mathrm{P}_{6}$ and $\mathrm{P}_{3}$, but both were non-significant (Table $2 \mathrm{~b}$ ). Other parents showed negative significant effects for the trait. Hence, parent $P_{1}$ was the good general combiner to use in crossing to improve the average single fruit weight.

The parent $\mathrm{P}_{1}$ had highly positive significant $S C A$ effects $\left(0.28^{* *}\right)$ for fruit yield per vine $(1.22 \mathrm{~kg}$ ) (Table $2 \mathrm{~b})$. All other parents showed negative significant effects for this trait. Hence, $\mathrm{P}_{1}$ was the good general combiner to use in crossing to improve the fruit bearing capacity per vine and total yield.

Highly significant $\left(1.43^{* *}\right)$ and the highest positive GCA effect for fruit length $(18.67 \mathrm{~cm})$ was found in $\mathrm{P}_{3}$ followed by $\mathrm{P}_{1}\left(1.35^{* *}\right)$ and $\mathrm{P}_{6}\left(0.28^{* *}\right)$ (Table $\left.2 \mathrm{~b}\right)$. The other parents showed either insignificant or negative significant values for this trait. Thus, $\mathrm{P}_{3}$ was the best general combiner to use in hybridization program to improve the length of fruit. Parents $\mathrm{P} 1$ and $\mathrm{P}_{6}$ may be considered as alternate parents for this trait (Table $2 b$ ).

The parent $\mathrm{P}_{5}$ had highly significant $\left(0.22^{* *}\right)$ and the highest positive GCA effect for fruit diameter $(4.50 \mathrm{~mm})$ followed by $\mathrm{P}_{1}\left(0.19^{*}\right)$ (Table $2 \mathrm{~b}$ ). Other parents showed negative significant effects for this trait. Hence, $\mathrm{P}_{5}$ and $\mathrm{P}_{1}$ were the good general combiners to use in crossing to improve fruit diameter.

Significant $\left(1.20^{*}\right)$ and the highest positive GCA effect for thickness of fruit flesh $(26.89 \mathrm{~mm})$ was found in $P_{5}$ followed by $\mathrm{P}_{1}\left(0.83^{*}, 26.52 \mathrm{~mm}\right)$. The other parents showed either insignificant or negative significant values for the trait (Table 2b). Thus $\mathrm{P}_{5}$ and $\mathrm{P}_{1}$ can be considered as better general combiners to use in hybridization program to improve thickness of the fruit flesh $(\mathrm{mm})$.

The parent $\mathrm{P}_{5}$ had significant $\left(0.31^{*}\right)$ and the highest positive GCA effect $(5.68 \mathrm{~mm})$ for fruit rind thickness followed by $\mathrm{P}_{1}\left(0.26^{*}, 5.63 \mathrm{~mm}\right)$. Other parents showed negative and insignificant effects for this trait (Table $2 b$ ). Hence, $\mathrm{P}_{5}$ and $\mathrm{P}_{1}$ were the good general combiners to use in crossing to improve the thickness of fruit rind $(\mathrm{mm})$.

Regarding days to green fruit maturity, three parents $\left(P_{2}, P_{3}\right.$ and $\left.P_{6}\right)$ provided positive GCA effects with parent

Table 2b. General combining ability effects for fruit yield and fruit characters in six bitter gourd genotypes.

\begin{tabular}{|c|c|c|c|c|c|c|c|}
\hline \multirow{3}{*}{ Parents } & \multicolumn{7}{|c|}{ Characters } \\
\hline & \multirow{2}{*}{$\begin{array}{l}\text { Number of } \\
\text { fruits per } \\
\text { vine (no.) }\end{array}$} & \multirow{2}{*}{$\begin{array}{l}\text { Av. Single } \\
\text { fruit weight } \\
\text { (g) }\end{array}$} & \multirow{2}{*}{$\begin{array}{l}\text { Fruit yield } \\
\text { per vine } \\
(\mathrm{kg})\end{array}$} & Fruit length & \multirow{2}{*}{$\begin{array}{c}\text { Fruit } \\
\text { diameter } \\
(\mathbf{c m})\end{array}$} & \multirow{2}{*}{$\begin{array}{l}\text { Thickness } \\
\text { of fruit } \\
\text { flesh }(\mathbf{m m})\end{array}$} & \multirow{2}{*}{$\begin{array}{c}\text { Thickness } \\
\text { of fruit rind } \\
(\mathrm{mm})\end{array}$} \\
\hline & & & & $(\mathrm{cm})$ & & & \\
\hline \multirow[t]{2}{*}{$P_{1}(B G 006)$} & $1.76^{* *}$ & $17.18^{* *}$ & $0.28^{* *}$ & $1.35^{* *}$ & $0.19^{*}$ & $0.83^{*}$ & $0.26^{*}$ \\
\hline & (12.94) & (107.03) & $(1.22)$ & (18.59) & $(4.47)$ & $(26.52)$ & $(5.63)$ \\
\hline \multirow[t]{2}{*}{$\mathrm{P}_{2}$ (BG 009) } & $0.69^{*}$ & $-8.46^{* *}$ & -0.01 & 0.30 & -0.08 & -0.45 & -0.23 \\
\hline & (11.87) & (81.39) & $(0.93)$ & $(17.54)$ & $(4.20)$ & $(25.24)$ & $(5.14)$ \\
\hline \multirow[t]{2}{*}{$\mathrm{P}_{3}(\mathrm{BG} 011)$} & $-1.49^{* *}$ & 0.67 & -0.04 & $1.43^{* *}$ & $-0.20^{*}$ & $-0.85^{*}$ & -0.15 \\
\hline & $(9.70)$ & $(90.52)$ & $(0.90)$ & (18.67) & $(4.08)$ & $(24.84)$ & $(5.22)$ \\
\hline \multirow[t]{2}{*}{$\mathrm{P}_{4}(\mathrm{BG} 027)$} & $1.4^{* *}$ & $-22.07^{* *}$ & $-0.15^{* *}$ & $-2.48^{* *}$ & $-0.15^{*}$ & $-0.86^{*}$ & -0.18 \\
\hline & $(12.58)$ & (67.79) & $(0.78)$ & $(14.77)$ & $(4.13)$ & $(24.83)$ & (5.19) \\
\hline \multirow[t]{2}{*}{$P_{5}(B G 033)$} & $-1.12^{* *}$ & $-10.84^{* *}$ & -0.03 & $-0.87^{* *}$ & $0.22^{* *}$ & $1.20^{*}$ & $0.31^{*}$ \\
\hline & (10.07) & (100.69) & $(0.90)$ & (16.38) & $(4.50)$ & (26.89) & $(5.68)$ \\
\hline \multirow[t]{2}{*}{$\mathrm{P}_{6}(\mathrm{BG} 036)$} & $-1.24^{* *}$ & 1.84 & -0.05 & $0.28^{* *}$ & 0.02 & 0.12 & -0.01 \\
\hline & $(9.94)$ & (91.69) & $(0.89)$ & $(17.52)$ & $(4.30)$ & $(25.81)$ & $(5.36)$ \\
\hline SE gi & 0.26 & 1.2 & 0.03 & 0.26 & 0.05 & 0.29 & 0.09 \\
\hline SE(gi-gj) & 0.41 & 1.86 & 0.04 & 0.40 & 0.08 & 0.46 & 0.14 \\
\hline
\end{tabular}

Figures in the parenthesis are the mean values. *Significant at $5 \%$ level of probability; ${ }^{* *}$ Significant at $1 \%$ level of probability. Non staric means non-significant up to $5 \%$ level of probability. 
$\mathrm{P}_{2}$ only having significant $\left(0.84^{*}\right)$ GCA effects with the maximum days (16.27 days) to green fruit maturity. While the other three parents $\left(\mathrm{P}_{1}, \mathrm{P}_{4}\right.$ and $\left.\mathrm{P}_{5}\right)$ provided non-significant negative GCA effects (Table 2c). However, since positive GCA effects are undesirable for general combiner to promote earliness, from among the parents with negative GCA effects, parent P4 had the least days to green fruit maturity (14.75 days), followed by P5 (14.89 days) and P1 (15.22 days). Therefore, P4 can be considered as the best general combiner for early fruit maturity in this crop. Parents $\mathrm{P}_{5}$ may be considered as alternate parent for this trait.

Regarding days to seed fruit maturity, parents $\mathrm{P}_{2}, \mathrm{P}_{5}$ and $\mathrm{P}_{6}$ had positive GCA effects and thus were undesirable general combiner for early seed fruit maturity for bitter gourd (Table $2 \mathrm{c}$ ). While parents $\mathrm{P}_{1}, \mathrm{P}_{3}$ and $\mathrm{P}_{4}$ provided negative GCA effects with parent $\mathrm{P}_{4}$ only having significant $\left(-0.67^{*}\right)$ GCA effects with the earliest 21.91 days to seed fruit maturity. Hence, $\mathrm{P}_{4}$ was the best general combiner for early seed fruit maturity for this crop.

GCA effects for number of seeds per fruit were not significant for any parents (Table 2c). Parent $\mathrm{P}_{5}$ showed the highest and positive GCA effects (22.96 seeds per fruit) followed by $\mathrm{P}_{2}$ and $\mathrm{P}_{1}$ which were undesirable for this trait. The parent $\mathrm{P}_{3}$ showed highest negative GCA effect (15.89 seeds per fruit) for this character, followed by $\mathrm{P}_{6}(16.58$ seeds per fruit) and $\mathrm{P}_{4}$ (17.10 seeds per fruit). Hence, $\mathrm{P}_{3}$ was the good general combiner for less seeded type.

Four parents, namely $\mathrm{P}_{1}, \mathrm{P}_{2}, \mathrm{P}_{5}$ and $\mathrm{P}_{6}$ had positive GCA effects for seed weight per fruit, having $P_{5}$ only with significant $\left(0.24^{*}\right)$ and the maximum seed weigh per fruit $(2.91 \mathrm{~g})$ and thus these parents were undesirable general combiner for this trait (Table 2c). While parents $\mathrm{P}_{3}$ and $\mathrm{P}_{4}$ provided with significant negative GCA effects with 2.44 and $2.47 \mathrm{~g}$ seeds per fruit. Hence, $\mathrm{P}_{3}$ and $\mathrm{P}_{4}$ were the best general combiner for fruits with lesser number of seeds.

The parent $\mathrm{P}_{6}$ showed highly significant $\left(1.37^{* *}\right)$ and the highest positive GCA effects for 100 seed weight (16.41 g) followed by $P_{1}$ and $P_{3}$. The other parents showed negative significant or non-significant effects for the trait. As positive GCA effects are desirable for this trait, $\mathrm{P}_{6}$ was the good general combiners for this character.

Considering GCA effects, the parent $\mathrm{P}_{2}$ was the best for early male and female flower opening. The parents $\mathrm{P}_{4}$ and $\mathrm{P}_{5}$ were found good combiner for dwarf plant type, more number of fruits and higher yield per plant. The parent $P_{3}$ was the best combiner for long type fruit. The parents $P_{1}$ was found good for average fruit weight and fruit yield. Taking all these characters into account, the parent $\mathrm{P}_{1}$ was identified as the best general combiner.

Podder et al. (2010) noted that general combiner for fruits per plant, fruit length, node number of first male and female flower among the six varied lines of snake gourd. They concluded that the parental line SG001 was the best general combiner for fruit weight. Balat et al. (2021) reported from a combining ability analysis of long fruited bottle gourd with the highest GCA effects for days to open first male flower, days to open first female flower, days to first harvest, number of fruits per plant, and total yield per plant. Mishra and Singh (2018) noted that the bitter gourd (VNR-28) showed the highest GCA effects for the total yield, fruit length, and fruit number per plant. The parent VNR-22 had maximum GCA effects for fruit weight, seeds per fruit, seed weight per fruit, fruit length, and vine length in bitter gourd. Valyaie et al. (2021) observed that the parent No. 484 was a good general combiner for fruit

Table 2c. General combining ability effects for days to fruit maturity and seed characters in six bitter gourd genotypes.

\begin{tabular}{|c|c|c|c|c|c|c|c|}
\hline \multirow{3}{*}{ Parents } & \multicolumn{7}{|c|}{ Characters } \\
\hline & \multirow{2}{*}{$\begin{array}{l}\text { Number of } \\
\text { fruits per } \\
\text { vine (no.) }\end{array}$} & \multirow{2}{*}{$\begin{array}{l}\text { Av. Single } \\
\text { fruit weight } \\
\text { (g) }\end{array}$} & \multirow{2}{*}{$\begin{array}{l}\text { Fruit yield } \\
\text { per vine } \\
(\mathrm{kg})\end{array}$} & Fruit length & \multirow{2}{*}{$\begin{array}{c}\text { Fruit } \\
\text { diameter } \\
(\mathbf{c m})\end{array}$} & \multirow{2}{*}{$\begin{array}{l}\text { Thickness } \\
\text { of fruit } \\
\text { flesh }(\mathbf{m m})\end{array}$} & \multirow{2}{*}{$\begin{array}{c}\text { Thickness } \\
\text { of fruit rind } \\
(\mathrm{mm})\end{array}$} \\
\hline & & & & $(\mathrm{cm})$ & & & \\
\hline \multirow[t]{2}{*}{$P_{1}(B G 006)$} & $1.76^{* *}$ & $17.18^{* *}$ & $0.28^{* *}$ & $1.35^{* *}$ & $0.19^{*}$ & $0.83^{*}$ & $0.26^{*}$ \\
\hline & (12.94) & (107.03) & $(1.22)$ & (18.59) & $(4.47)$ & $(26.52)$ & $(5.63)$ \\
\hline \multirow[t]{2}{*}{$\mathrm{P}_{2}$ (BG 009) } & $0.69^{*}$ & $-8.46^{* *}$ & -0.01 & 0.30 & -0.08 & -0.45 & -0.23 \\
\hline & (11.87) & (81.39) & $(0.93)$ & $(17.54)$ & $(4.20)$ & $(25.24)$ & $(5.14)$ \\
\hline \multirow[t]{2}{*}{$\mathrm{P}_{3}(\mathrm{BG} 011)$} & $-1.49^{* *}$ & 0.67 & -0.04 & $1.43^{* *}$ & $-0.20^{*}$ & $-0.85^{*}$ & -0.15 \\
\hline & $(9.70)$ & $(90.52)$ & $(0.90)$ & (18.67) & $(4.08)$ & $(24.84)$ & $(5.22)$ \\
\hline \multirow[t]{2}{*}{$\mathrm{P}_{4}(\mathrm{BG} 027)$} & $1.4^{* *}$ & $-22.07^{* *}$ & $-0.15^{* *}$ & $-2.48^{* *}$ & $-0.15^{*}$ & $-0.86^{*}$ & -0.18 \\
\hline & $(12.58)$ & (67.79) & $(0.78)$ & $(14.77)$ & $(4.13)$ & $(24.83)$ & (5.19) \\
\hline \multirow[t]{2}{*}{$P_{5}(B G 033)$} & $-1.12^{* *}$ & $-10.84^{* *}$ & -0.03 & $-0.87^{* *}$ & $0.22^{* *}$ & $1.20^{*}$ & $0.31^{*}$ \\
\hline & (10.07) & (100.69) & $(0.90)$ & (16.38) & $(4.50)$ & (26.89) & $(5.68)$ \\
\hline \multirow[t]{2}{*}{$\mathrm{P}_{6}(\mathrm{BG} 036)$} & $-1.24^{* *}$ & 1.84 & -0.05 & $0.28^{* *}$ & 0.02 & 0.12 & -0.01 \\
\hline & $(9.94)$ & (91.69) & $(0.89)$ & $(17.52)$ & $(4.30)$ & $(25.81)$ & $(5.36)$ \\
\hline SE gi & 0.26 & 1.2 & 0.03 & 0.26 & 0.05 & 0.29 & 0.09 \\
\hline SE(gi-gj) & 0.41 & 1.86 & 0.04 & 0.40 & 0.08 & 0.46 & 0.14 \\
\hline
\end{tabular}

Figures in the parenthesis are the mean values. ${ }^{*}$ Significant at $5 \%$ level of probability; ${ }^{* *}$ Significant at $1 \%$ level of probability. Non static means non-significant up to $5 \%$ level of probability. 
weight, yield per plot, days to first female flower, first female flowering node and fruits per plant in bitter gourd. Rajkumar et al. (2019) obtained information on line X tester analysis on seven yield components in snake gourd. They noted that GCA effects for yield per plant and fruits per plant were significant for the lines TA- 102, TA-100 and TA-89. The lines TA-82 and TA-77 were good combiners for earliness. In combining ability analysis of bitter gourd, Malve et al. (2021) noted that Phule Green Gold were the best general combiners for number of seeds per fruit. They also reported Phule Green Gold, Preethi and Arka Harit were good combiners for 100 -seed weight. Thangamani et al. (2011) observed that the parents Preethi, CO-1, MC-30, Uchha Bolder, Green Long, MC-105 had highly significant and positive GCA effects for yield per vine, fruit weight, fruit length and fruit diameter in bitter gourd. Mishra and Singh (2018) noted that US-33 was the best general combiner for yield, fruit weight and fruit size in a five line and two testers cross in bitter gourd. The variety VNR-22 had the highest number of fruits per plant and consistent values of GCA effects followed by VNR-28 and MC-84.

\subsection{Specific combining ability effects (SCA)}

The SCA effects signify the role of non-additive gene action in the expression of the characters. It indicates the highly specific combining ability leading to highest performance of some specific cross combinations. That is why it is related to a particular cross. High SCA effects may arise not only in crosses involving high combiners but also in those involving low combiners. Thus in practice, some of the low combiners should also be accommodated in hybridization program. The SCA effects of $15 \mathrm{~F}_{1}$ crosses for 19 characters studied are presented in Table 3a, 3b and 3c.

Out of the $15 \mathrm{~F}_{1}$ s, six showed negative SCA values (Table 3a) indicating that there was considerable heterosis for this character and at least $40 \%$ of the hybrids flowered earlier than the means of their parents. Out of the crosses, four crosses showed highly significant negative SCA values with the largest negative values in crosses $\mathrm{P}_{2} \times \mathrm{P}_{6}$ $\left(-2.94^{* *}\right), \mathrm{P}_{3} \times \mathrm{P}_{5}\left(-2.07^{* *}\right), \mathrm{P}_{1} \times \mathrm{P}_{3}\left(-1.55^{*}\right), \mathrm{P}_{5} \times \mathrm{P}_{6}\left(1.26^{*}\right)$ and was the best specific combiner for early flowering. While the crosses $\mathrm{P}_{4} \times \mathrm{P}_{6}\left(3.78^{* *}\right)$ and $\mathrm{P}_{1} \times \mathrm{P}_{5}\left(2.02^{* *}\right)$ showed significant positive SCA effect which produced later flowering than their mean value.

The highest significant and positive SCA effects for this trait was exhibited by the cross $\mathrm{P}_{4} \times \mathrm{P}_{6}\left(3.02^{* *}\right)$. The other combinations showing significant and positive SCA effects were $\mathrm{P}_{3} \times \mathrm{P}_{5}\left(2.59^{* *}\right), \mathrm{P}_{4} \times \mathrm{P}_{5}\left(2.48^{* *}\right)$ and $\mathrm{P}_{2} \times \mathrm{P}_{3}$ $\left(1.78^{*}\right)$. The cross combination $\mathrm{P}_{2} \times \mathrm{P}_{5}$ showed highest and negative SCA effects $\left(-2.94^{* *}\right)$. Thus the cross, $\mathrm{P}_{2} \times \mathrm{P}_{5}$ was the best specific combination for this trait because flower in lower node is desirable.

Out of the $15 \mathrm{~F}_{1} \mathrm{~s}$, seven showed negative SCA values indicating that these hybrids produced early female flower than the mean of the better parent. The highest positive significant SCA value was obtained from hybrid $\mathrm{P}_{1} \times \mathrm{P}_{5}$ (3.30*) followed by $\mathrm{P}_{3} \times \mathrm{P}_{4}\left(2.69^{*}\right)$ and $\mathrm{P}_{2} \times \mathrm{P}_{5}\left(2.61^{*}\right)$, which delayed the female flowering. So, $\mathrm{P}_{1} \times \mathrm{P}_{2}\left(-2.65^{*}\right)$ and $\mathrm{P}_{3}$ $x \mathrm{P}_{5}\left(-2.17^{*}\right)$ was the best specific combination for early flowering and fruiting (Table $3 a$ )

Table 3a. Estimates of SCA effects of crosses for days to flower and growth characters in six bitter gourd genotypes.

\begin{tabular}{|c|c|c|c|c|c|c|c|}
\hline \multirow[b]{2}{*}{ Crosses } & \multicolumn{7}{|c|}{ Characters } \\
\hline & $\begin{array}{l}\text { Days to first } \\
\text { male flower } \\
\text { opening }\end{array}$ & $\begin{array}{c}\text { Node } \\
\text { number of } \\
\text { first male } \\
\text { flower }\end{array}$ & $\begin{array}{c}\text { Days to } \\
\text { first female } \\
\text { flower } \\
\text { opening }\end{array}$ & $\begin{array}{c}\text { Node } \\
\text { number of } \\
\text { first female } \\
\text { flower }\end{array}$ & $\begin{array}{l}\text { Main vine } \\
\text { length } \\
(\mathrm{m})\end{array}$ & $\begin{array}{c}\text { No. of } \\
\text { primary } \\
\text { branches } \\
\text { per vine }\end{array}$ & $\begin{array}{c}\text { No. of nodes } \\
\text { per main } \\
\text { vine (no.) }\end{array}$ \\
\hline $\mathrm{P}_{1} \mathrm{xP}_{2}$ & 0.93 & 0.63 & $-2.65^{*}$ & $-2.79^{*}$ & -0.14 & 0.30 & -0.28 \\
\hline $\mathrm{P}_{1} \mathrm{XP}_{3}$ & $-1.55^{*}$ & -0.36 & -1.57 & $-2.43^{* *}$ & -0.25 & 0.19 & -2.60 \\
\hline $\mathrm{P}_{1} \times \mathrm{P}_{4}$ & -0.01 & -0.23 & 0.30 & 0.93 & $0.38^{* *}$ & -0.02 & -0.49 \\
\hline $\mathrm{P}_{1} \mathrm{XP}_{5}$ & $2.02^{* *}$ & 0.03 & $3.30^{* *}$ & 0.72 & $-0.43^{*}$ & 0.21 & $-7.01^{* *}$ \\
\hline $\mathrm{P}_{1} \times \mathrm{P}_{6}$ & -0.60 & 0.10 & -0.27 & $3.50^{* *}$ & -0.16 & $-0.67^{* *}$ & -0.38 \\
\hline $\mathrm{P}_{2} \mathrm{XP}_{3}$ & 0.83 & $1.78^{*}$ & 0.91 & -1.20 & -0.17 & -0.26 & $-6.08^{*}$ \\
\hline $\mathrm{P}_{2} \mathrm{XP}_{4}$ & 0.70 & 0.67 & -0.06 & 0.19 & -0.002 & $-0.71^{* *}$ & -1.79 \\
\hline $\mathrm{P}_{2} \mathrm{XP}_{5}$ & 0.85 & $-2.94^{* *}$ & $2.61^{*}$ & 0.32 & $0.35^{*}$ & -0.07 & 3.09 \\
\hline $\mathrm{P}_{2} \mathrm{XP}_{6}$ & $-2.94^{* *}$ & -0.92 & -1.30 & -0.30 & 0.31 & $0.81^{* *}$ & $5.03^{*}$ \\
\hline $\mathrm{P}_{3} \mathrm{XP}_{4}$ & $1.31^{*}$ & 1.00 & $2.69^{*}$ & 0.54 & -0.09 & 0.16 & -0.35 \\
\hline $\mathrm{P}_{3} \times \mathrm{P}_{5}$ & $-2.07^{* *}$ & $2.59^{* *}$ & $-2.17^{*}$ & $3.23^{*}$ & 0.18 & -0.08 & 3.63 \\
\hline $\mathrm{P}_{3} \mathrm{XP}_{6}$ & 0.72 & 0.36 & 0.87 & $-2.08^{*}$ & 0.19 & 0.35 & 1.41 \\
\hline $\mathrm{P}_{4} \mathrm{XP}_{5}$ & 0.46 & $2.48^{* *}$ & -0.69 & 0.40 & 0.16 & -0.05 & 4.37 \\
\hline $\mathrm{P}_{4} \mathrm{xP}_{6}$ & $3.78^{* *}$ & $3.02^{* *}$ & $2.53^{*}$ & $2.67^{*}$ & -0.10 & 0.15 & 0.35 \\
\hline $\mathrm{P}_{5} \mathrm{XP}_{6}$ & $-1.26^{*}$ & -0.72 & 0.07 & -0.70 & -0.26 & -0.09 & -2.69 \\
\hline $\mathrm{SE}(\mathrm{sij})$ & 0.54 & 0.65 & 0.99 & 0.73 & 0.15 & 0.17 & 2.31 \\
\hline
\end{tabular}

${ }^{*}$ Significant at $5 \%$ level of probability; ${ }^{* *}$ Significant at $1 \%$ level of probability. Non-strike means non-significant up to $5 \%$ level of probability. 
Table 3b. Estimates of SCA effects of crosses for fruit yield and fruit characters in six bitter gourd genotypes.

\begin{tabular}{|c|c|c|c|c|c|c|c|}
\hline \multirow[b]{2}{*}{ Crosses } & \multicolumn{7}{|c|}{ Characters } \\
\hline & $\begin{array}{l}\text { Number of } \\
\text { fruits per } \\
\text { vine (no.) }\end{array}$ & $\begin{array}{c}\text { Av. Single } \\
\text { fruit weight } \\
\text { (g) }\end{array}$ & $\begin{array}{l}\text { Fruit yield } \\
\text { per vine } \\
(\mathrm{kg})\end{array}$ & $\begin{array}{l}\text { Fruit length } \\
\qquad(\mathrm{cm})\end{array}$ & $\begin{array}{c}\text { Fruit } \\
\text { diameter } \\
(\mathbf{c m})\end{array}$ & $\begin{array}{l}\text { Thickness } \\
\text { of fruit } \\
\text { flesh }(\mathrm{mm})\end{array}$ & $\begin{array}{c}\text { Thickness } \\
\text { of fruit rind } \\
(\mathrm{mm})\end{array}$ \\
\hline $\mathrm{P}_{1} \mathrm{xP}_{2}$ & 0.47 & $7.03^{*}$ & $-0.19^{* *}$ & -0.43 & 0.18 & $1.91^{*}$ & 0.47 \\
\hline $\mathrm{P}_{1} \mathrm{xP}_{3}$ & -0.38 & $19.07^{* *}$ & $0.11^{* *}$ & $0.96^{*}$ & -0.23 & $-1.92^{*}$ & -0.08 \\
\hline $\mathrm{P}_{1} \mathrm{XP}_{4}$ & -0.63 & -0.65 & $0.23^{* *}$ & $0.81^{*}$ & -0.003 & 0.27 & -0.22 \\
\hline $\mathrm{P}_{1} \mathrm{XP}_{5}$ & $-2.86^{* *}$ & $10.69^{*}$ & $-0.22^{* *}$ & 0.54 & -0.08 & $-1.80^{*}$ & 0.26 \\
\hline $\mathrm{P}_{1} \mathrm{xP}_{6}$ & 0.21 & $-7.18^{*}$ & -0.01 & -0.14 & 0.04 & 0.63 & -0.14 \\
\hline $\mathrm{P}_{2} \mathrm{xP}_{3}$ & $-2.97^{* *}$ & $12.31^{* *}$ & $-0.15^{* *}$ & $1.08^{*}$ & -0.19 & -2.21 & 0.17 \\
\hline $\mathrm{P}_{2} \mathrm{XP}_{4}$ & $3.57^{* *}$ & 1.38 & $0.15^{* *}$ & -0.21 & -0.02 & -0.21 & 0.28 \\
\hline $\mathrm{P}_{2} \mathrm{xP}_{5}$ & $2.63^{* *}$ & $-22.67^{* *}$ & -0.02 & 0.56 & -0.06 & -0.31 & -0.42 \\
\hline $\mathrm{P}_{2} \mathrm{xP}_{6}$ & -0.17 & 2.05 & $0.10^{* *}$ & $-1.25^{*}$ & -0.09 & -0.78 & -0.10 \\
\hline $\mathrm{P}_{3} \mathrm{xP}_{4}$ & 0.32 & $-8.05^{*}$ & $-0.13^{* *}$ & -0.11 & -0.11 & -0.85 & 0.03 \\
\hline $\mathrm{P}_{3} \mathrm{xP}_{5}$ & $2.47^{* *}$ & $14.52^{* *}$ & $0.35^{* *}$ & -0.23 & 0.44 & $2.82^{* *}$ & 0.01 \\
\hline $\mathrm{P}_{3} \mathrm{xP}_{6}$ & 0.32 & $-19.66^{* *}$ & -0.02 & $-1.66^{*}$ & 0.13 & 0.63 & 0.46 \\
\hline $\mathrm{P}_{4} \mathrm{xP}_{5}$ & $-2.19^{* *}$ & 4.16 & -0.04 & 0.62 & -0.01 & -0.04 & 0.31 \\
\hline $\mathrm{P}_{4} \mathrm{xP}_{6}$ & $2.66^{* *}$ & 1.83 & $0.14^{* *}$ & 0.40 & 0.15 & 1.13 & 0.02 \\
\hline $\mathrm{P}_{5} \mathrm{xP}_{6}$ & -0.16 & -4.56 & $-0.10^{* *}$ & 0.36 & -0.20 & -1.17 & -0.32 \\
\hline $\mathrm{SE}(\mathrm{sij})$ & 0.60 & 2.73 & 0.02 & 0.59 & 0.12 & 0.79 & 0.34 \\
\hline
\end{tabular}

${ }^{*}$ Significant at $5 \%$ level of probability; **Significant at $1 \%$ level of probability. Non-strike means non-significant up to $5 \%$ level of probability.

Table 3c. Estimates of SCA effects of crosses for days to maturity and seed characters in six bitter gourd genotypes.

\begin{tabular}{|c|c|c|c|c|c|}
\hline \multirow[b]{2}{*}{ Crosses } & \multicolumn{5}{|c|}{ Character } \\
\hline & $\begin{array}{l}\text { Days to green } \\
\text { fruit maturity }\end{array}$ & $\begin{array}{c}\text { Days to seed fruit } \\
\text { maturity }\end{array}$ & $\begin{array}{c}\text { Number of seed } \\
\text { per fruit }\end{array}$ & $\begin{array}{l}\text { Seed weight per } \\
\text { fruit }(\mathrm{g})\end{array}$ & $\begin{array}{c}\text { 100-seed weight } \\
(\mathrm{g})\end{array}$ \\
\hline $\mathrm{P}_{1} \mathrm{xP}_{2}$ & -0.22 & -0.23 & $2.91^{* *}$ & $0.44^{*}$ & -0.05 \\
\hline $\mathrm{P}_{1} \mathrm{xP}_{3}$ & -0.73 & -0.04 & -0.57 & $-0.36^{*}$ & $-1.65^{* *}$ \\
\hline $\mathrm{P}_{1} \mathrm{xP}_{4}$ & 1.07 & -0.25 & $-4.24^{* *}$ & $0.42^{*}$ & $1.21^{* *}$ \\
\hline $\mathrm{P}_{1} \mathrm{xP}_{5}$ & -0.97 & 0.77 & 0.50 & -0.11 & $-1.08^{*}$ \\
\hline $\mathrm{P}_{1} \mathrm{XP}_{6}$ & -0.30 & 0.70 & $1.25^{*}$ & 0.02 & -0.08 \\
\hline $\mathrm{P}_{2} \mathrm{xP}_{3}$ & $-1.58^{*}$ & -0.55 & $-2.16^{*}$ & -0.19 & $1.09^{*}$ \\
\hline $\mathrm{P}_{2} \mathrm{xP}_{4}$ & -0.05 & 0.47 & $-1.47^{*}$ & -0.21 & -0.26 \\
\hline $\mathrm{P}_{2} \mathrm{xP}_{5}$ & $1.22^{*}$ & $-1.05^{*}$ & $3.08^{* *}$ & $0.54^{* *}$ & 0.13 \\
\hline $\mathrm{P}_{2} \mathrm{xP}_{6}$ & 0.97 & -0.16 & $-1.80^{*}$ & -0.19 & 0.65 \\
\hline $\mathrm{P}_{3} \mathrm{xP}_{4}$ & 1.06 & -0.32 & $1.89^{*}$ & 0.09 & $-1.12^{* *}$ \\
\hline $\mathrm{P}_{3} \times \mathrm{P}_{5}$ & 0.57 & 0.86 & $-1.01^{*}$ & -0.13 & 0.24 \\
\hline $\mathrm{P}_{3} \mathrm{xP}_{6}$ & 0.79 & -0.41 & $2.19^{* *}$ & 0.30 & 0.47 \\
\hline $\mathrm{P}_{4} \mathrm{xP}_{5}$ & -0.62 & -0.24 & 0.08 & -0.06 & 0.33 \\
\hline $\mathrm{P}_{4} \mathrm{xP}_{6}$ & -0.09 & 0.42 & 0.81 & $0.53^{* *}$ & $1.61^{* *}$ \\
\hline $\mathrm{P}_{5} \mathrm{xP}_{6}$ & $-1.30^{*}$ & -0.28 & $-3.56^{* *}$ & $-0.71^{* *}$ & $-1.09^{* *}$ \\
\hline $\mathrm{SE}(\mathrm{sij})$ & 0.52 & 0.41 & 0.47 & 0.17 & -0.38 \\
\hline
\end{tabular}

${ }^{*}$ Significant at $5 \%$ level of probability; ** Significant at $1 \%$ level of probability. Non-strike means non-significant up to $5 \%$ level of probability.

The cross combinations, $\mathrm{P}_{1} \times \mathrm{P}_{6}\left(3.50^{* *}\right)$ followed by $\quad$ On the other hand, $\mathrm{P}_{1} \times \mathrm{P}_{2}\left(-2.79^{*}\right)$ followed by $\mathrm{P}_{1} \times \mathrm{P}_{3}$ $\mathrm{P}_{3} \times \mathrm{P}_{5}\left(3.23^{* *}\right)$ and $\mathrm{P}_{4} \times \mathrm{P}_{6}$ showed maximum significant $\left(-2.43^{* *}\right)$ and $\mathrm{P}_{3} \times \mathrm{P}_{6}\left(-2.08^{*}\right)$ showed significant negative and positive SCA effect for this trait which is undesirable. heterosis than the mean of the better parent. So cross 
combination which had negative SCA value is the best for improving this trait.

Among the cross combinations about $60 \% \mathrm{~F}_{1}$ s showed negative SCA values for this trait (Table 3a). This indicates that these $F_{1}$ s produced shorter vine compared to the mean of the better parents. Most of the negative SCA value was insignificant except one $\mathrm{P}_{1} \mathrm{X}_{5}\left(-0.43^{*}\right)$. Rest five crosses showed positive SCA value but two was significant.

SCA value of the three crosses (one positive and two negative) was significant among the 15 crosses. In other 12 combinations, six showed positive and six showed negative but insignificant SCA effect. So the cross $\mathrm{P}_{1} \times \mathrm{P}_{6}$ $\left(0.67^{* *}\right)$ was the best for this trait.

Among the cross combinations, $\mathrm{P}_{2} \times \mathrm{P}_{6}\left(5.03^{* *}\right)$ showed the highest significant and positive SCA effect for this character followed by $\mathrm{P}_{4} \times \mathrm{P}_{6}, \mathrm{P}_{3} \times \mathrm{P}_{5}$ and $\mathrm{P}_{2} \times \mathrm{P}_{5}$. On the other hand, the cross $\mathrm{P}_{1} \times \mathrm{P}_{5}$ showed the highest significant and negative SCA effect (7.01) followed by $\mathrm{P}_{2} \times \mathrm{P}_{3}\left(-6.08^{*}\right)$, $\mathrm{P}_{5} \times \mathrm{P}_{6}(-2.69)$ and $\mathrm{P}_{1} \times \mathrm{P}_{3}(-2.60)$ (Table 3a). Thus, the combination $\mathrm{P}_{2} \times \mathrm{P}_{6}$ may be considered as the best specific combiner to enhance the nodes on main vine.

Out of the $15 \mathrm{~F}_{1} \mathrm{~s}$, eight showed the positive and six showed the negative SCA values (Table 3a). Among the cross combinations, $\mathrm{P}_{2} \times \mathrm{P}_{4}\left(3.57^{* *}\right)$ showed the highest significant and positive SCA effects for this character followed by $\mathrm{P}_{4} \times \mathrm{P}_{6}, \mathrm{P}_{2} \times \mathrm{P}_{5}$ and $\mathrm{P}_{3} \times \mathrm{P}_{5}$. On the other hand, the cross $\mathrm{P}_{2} \times \mathrm{P}_{3}\left(-2.97^{* *}\right)$ showed the highest significant but negative SCA effects for this trait followed by $\mathrm{P}_{1} \times \mathrm{P}_{5}$ $\left(-2.86^{* *}\right)$ and $\mathrm{P}_{4} \times \mathrm{P}_{5}\left(-2.19^{* *}\right)$. Other combinations showed insignificant values for this parameter. Hence, the cross combination $\mathrm{P}_{2} \times \mathrm{P}_{4}$ was the best specific combiner to increase number of fruits per vine (Table $3 \mathrm{~b}$ )

The cross combination $\mathrm{P}_{1} \times \mathrm{P}_{3}\left(19.07^{* *}\right)$ exhibited the highest significant and positive SCA effect followed by $\mathrm{P}_{3}$ $x \mathrm{P}_{5}\left(14.52^{* *}\right)$ and $\mathrm{P}_{2} \times \mathrm{P}_{3}\left(12.31^{* *}\right)$ for average single fruit weight. Significant and positive moderate values for this parameter were obtained from combinations $\mathrm{P}_{1} \times \mathrm{P}_{5}$ and $\mathrm{P}_{1} \times \mathrm{P}_{2}$. On the other hand, $\mathrm{P}_{2} \times \mathrm{P}_{5}$ showed the highest negative SCA effect $\left(-22.67^{* *}\right)$ followed by the cross $\mathrm{P}_{3} \mathrm{x}$ $\mathrm{P}_{6}\left(-19.66^{* *}\right), \mathrm{P}_{3} \times \mathrm{P}_{4}\left(-8.05^{* *}\right)$. The crosses $\mathrm{P}_{2} \times \mathrm{P}_{4}, \mathrm{P}_{2} \times \mathrm{P}_{6}$, $\mathrm{P}_{4} \times \mathrm{P}_{5}$ and $\mathrm{P}_{4} \times \mathrm{P}_{6}$ showed positive but insignificant SCA effect. Hence, $\mathrm{P}_{1} \times \mathrm{P}_{3}$ was the best specific combinations to increase the average single fruit weight but $\mathrm{P}_{1} \mathrm{x}_{2}$ and $\mathrm{P}_{1} \times \mathrm{P}_{5}$ was the best combinations if we desire moderate average single fruit weight.

The cross combination $\mathrm{P}_{1} \times \mathrm{P}_{3}, \mathrm{P}_{1} \times \mathrm{P}_{4}, \mathrm{P}_{2} \times \mathrm{P}_{4}, \mathrm{P}_{2} \times \mathrm{P}_{6}$, $\mathrm{P}_{3} \times \mathrm{P}_{5}$ and $\mathrm{P}_{4} \times \mathrm{P}_{6}$ exhibited significant and positive SCA effects of which $\mathrm{P}_{3} \times \mathrm{P}_{5}$ provided maximum value $\left(0.35^{* *}\right)$ for the parameter fruit yield per vine ( $\mathrm{kg}$ ) (Table $3 \mathrm{~b})$. The other combination showed the negative significant or insignificant SCA effects. Thus, $\mathrm{P}_{3} \times \mathrm{P}_{5}$ was the best specific combination followed by $\mathrm{P}_{1} \times \mathrm{P}_{4}$ and $\mathrm{P}_{2} \times \mathrm{P}_{4}$.

Among $15 \mathrm{~F}_{1}$ hybrids, only three revealed significant and positive SCA values for this trait. The combination $\mathrm{P}_{2}$ $\mathrm{xP}_{3}\left(1.08^{* *}\right)$ exhibited the highest significant and positive value followed by $\mathrm{P}_{1} \times \mathrm{P}_{3}\left(0.96^{*}\right)$ and $\mathrm{P}_{1} \times \mathrm{P}_{4}\left(0.81^{*}\right)$. The combination of $\mathrm{P}_{3} \times \mathrm{P}_{6}\left(-1.66^{*}\right)$ showed highest significant and negative values for this trait followed by $\mathrm{P}_{2} \times \mathrm{P}_{6}$. Here, five combinations showed insignificant positive values and five combinations showed insignificant negative values.
Hence, the cross combination $\mathrm{P}_{2} \times \mathrm{P}_{3}$ was the best specific combination to get longest fruit in this crop.

All the crosses showed insignificant SCA effect but among them five were positive and ten was negative. There was less scope of changing the trait in this crop.

The highest significant and positive SCA effect for this trait was provided by the cross $\mathrm{P}_{3} \times \mathrm{P}_{5}\left(2.82^{* *}\right)$ followed by $\mathrm{P}_{1} \times \mathrm{P}_{2}$. The cross $\mathrm{P}_{1} \times \mathrm{P}_{3}$ provided the highest significant and negative SCA effect $\left(-1.92^{* *}\right)$ followed by $\mathrm{P}_{1} \times \mathrm{P}_{5}$. Other combinations showed insignificant positive and negative values for the trait. Thus, $\mathrm{P}_{1} \times \mathrm{P}_{3}$ was the best combination for reducing the fruit flesh thickness which is desirable.

There was no significant positive or negative SCA value for this trait. Out of $15 \mathrm{~F}_{1} \mathrm{~s}$, nine showed positive and six showed negative SCA values. So, there was less scope of changing the trait in this crop. Only three crosses showed significant SCA values, the cross combinations $\mathrm{P}_{2} \times \mathrm{P}_{5}$ showed significant positive value $\left(1.22^{*}\right)$, on the other hand, the crosses $\mathrm{P}_{2} \times \mathrm{P}_{3}\left(-1.58^{*}\right)$ and $\mathrm{P}_{5} \times \mathrm{P}_{6}\left(-1.30^{*}\right)$ showed negative significant value. Hence, the cross showing negative SCA value was the best cross for improving this trait. So, the cross combinations $\mathrm{P}_{2} \times \mathrm{P}_{3}$ and $\mathrm{P}_{5} \times \mathrm{P}_{6}$ provided opportunity for early maturity in this crop (Table $3 \mathrm{c}$ )

Nine crosses showed the negative SCA effect, but the only one cross $\left(\mathrm{P}_{2} \times \mathrm{P}_{5}\right)$ was significant. Other six crosses showed insignificant positive SCA effects for this trait. So, this cross combination $\mathrm{P}_{2} \mathrm{xP}_{5}$ was the best because it provides opportunity to early seed fruit maturity in this crop.

The cross combination $\mathrm{P}_{2} \times \mathrm{P}_{5}$ provided maximum value of the parameter followed by $\mathrm{P}_{1} \times \mathrm{P}_{2}, \mathrm{P}_{3} \times \mathrm{P}_{6}, \mathrm{P}_{3} \times \mathrm{P}_{4}$ and $\mathrm{P}_{1}$ $\mathrm{xP}_{6}$. On the other hand, cross $\mathrm{P}_{1} \mathrm{x}_{4}$ showed the highest negative significant value $\left(-4.24^{* *}\right)$ followed by $\mathrm{P} 5 \mathrm{x}_{6}, \mathrm{P}_{2}$ $\times \mathrm{P}_{3}, \mathrm{P}_{2} \times \mathrm{P}_{6}, \mathrm{P}_{2} \times \mathrm{P}_{4}$ and $\mathrm{P}_{3} \times \mathrm{P}_{5}$. The remaining four cross combinations had the insignificant SCA effect. Hence, the cross with high negative significant SCA effect, such as $\mathrm{P}_{1} \times \mathrm{P}_{4}, \mathrm{P}_{5} \times \mathrm{P}_{6}, \mathrm{P}_{2} \times \mathrm{P}_{3}$ was considered as the best specific combiner for less seeded fruit development.

Highest significant and positive SCA effects were observed in seed weight per fruit by the combination $\mathrm{P}_{2}$ $x \mathrm{P}_{5}\left(0.54^{* *}\right)$ followed by $\mathrm{P}_{4} \times \mathrm{P}_{6}\left(0.53^{* *}\right), \mathrm{P}_{1} \times \mathrm{P}_{2}\left(0.44^{* *}\right)$. On the other hand, the highest negative significant SCA effect was observed by the crosses $\mathrm{P}_{5} \times \mathrm{P}_{6}\left(-0.71^{* *}\right)$ followed by $\mathrm{P}_{1} \times \mathrm{P}_{3}\left(-0.36^{* *}\right), \mathrm{P}_{1} \times \mathrm{P}_{4}\left(0.42^{*}\right)$. Remaining nine crosses provided insignificant positive or negative SCA effect. Thus crosses $\mathrm{P}_{5} \times \mathrm{P}_{6}, \mathrm{P}_{1} \times \mathrm{P}_{3}$ and $\mathrm{P}_{1} \times \mathrm{P}_{4}$ was the best combinations for fruit development which contain small size fruit considering the weight (Table 3c).

Out of $15 \mathrm{~F}_{1} \mathrm{~s}$, seven crosses had significant positive or negative SCA value in 100-seed weight. The cross $\mathrm{P}_{4} \times \mathrm{P}_{6}$ showed the highest significant and positive value (1.61**) followed by $\mathrm{P}_{1} \times \mathrm{P}_{4}$ and $\mathrm{P}_{2} \times \mathrm{P}_{3}$. On the other hand, the cross combination $\mathrm{P}_{1} \times \mathrm{P}_{5}\left(-2.72^{* *}\right)$ showed the highest significant and negative value followed by $\mathrm{P}_{3} \times \mathrm{P}_{4}$ and $\mathrm{P}_{5}$ $\mathrm{xP}_{6}$. Thus, the crosses $\mathrm{P}_{1} \times \mathrm{P}_{5} \mathrm{P}_{3} \times \mathrm{P}_{4}$ and $\mathrm{P}_{5} \times \mathrm{P}_{6}$ were the best combinations for developing fruit which contain lesser weight of seed.

Based on SCA effects, the cross combination $\mathrm{P}_{1} \mathrm{x}_{3}$ was found superior for node number of first female flower, average single fruit weight, fruit yield per vine, fruit length, thickness of the fruit flesh, seed weight per fruit and 100 
seed weight. The cross $\mathrm{P}_{1} \times \mathrm{P}_{2}$ was found better for the characters days to first female flower and node number of first female flower. The cross combination $\mathrm{P}_{3} \times \mathrm{P}_{5}$ was best for most of the characters which were days to first male and female flower, node number of first female flower, number of fruits per vine, average single fruit weight and fruit yield per vine. The cross $\mathrm{P}_{2} \times \mathrm{P}_{4}$ may be selected for the number of fruits per vine and fruit yield per vine. Ahsan et al. (2011) reported that among the six diallel cross in snake gourd $\mathrm{P}_{1} \mathrm{xP}_{5}$ had significant $\mathrm{SCA}$ effects for days to first male and female flower opening with longest vine. The crosses $\mathrm{P}_{2} \times \mathrm{P}_{3}$ for earliness and $\mathrm{P}_{1} \times \mathrm{P}_{2}$ for weight of fruits per plant fruit length and 100 -seed weight. The cross $\mathrm{P}_{3} \mathrm{X}$ $P_{6}$ was the best for total fruits per plant. Devi et al. (2017b) observed that the cross combinations L2xT3, L7xT2, L2xT4, L5xT1 and L8xT4 exhibited high SCA effects for yield per plant and fruits per plant in snake gourd. Bahari et al. (2012) noted that specific combining ability accounted for a greater portion of the variability among crosses for vine length, number of fruits per plant and fruit weight in watermelon. Malve et al. (2021) reported that four parental lines of bitter gourd crosses viz., P1 x P2 (Phule Green Gold x Preethi), P2 X P5 (Preethi x DVBTG-7), P1x P3 (Phule Green Gold x Arka harit) and P6 x P7 (Hirkani x Konkan Tara) recorded high positive SCA effect as well as high mean performance for most of the characters. Jasim and Esho (2021) stated that the cross combination Kabak Sakiz x Mulla ahmad prolific had higher estimates of SCA for number of fruits as well as yield per plant in summer squash. They also reported that the cross vegetable Marrow x E.C. 33683 had the highest number of branches. Rani and Reddy (2017) observed the best specific combiners for vine length, days to first male and female flower, fruit length and girth were Arka Bahar x Pusa Summer Prolific Long, Arka Bahar x IC-92330, Arka Bahar x Tirupati local, Pusa Summer Prolific Long x Pratik, Pratik x IC-92330 and Pratik x Tirupati local, respectively, in bottle gourd. Napolitano et al. (2020) indicated that the combination PI414723 or PI161375 was the best specific combiner for yield per plot in melon (Cucumis melo L.)

\subsection{Reciprocal effects}

The reciprocal effects (rij) of $15 \mathrm{~F}_{1}$ crosses for nineteen different characters studied are presented in Table 4, 5 and 6 . The entire reciprocal cross performed better in some cases better than SCA effect. For that character wise reciprocal effect has been discussed in the following manner.

\subsection{Days to first male flower opening}

Highly significant and negative reciprocal effect was exhibited by the cross $\mathrm{P}_{3} \times \mathrm{P}_{1}\left(-4.42^{* *}\right)$ followed by the crosses $\mathrm{P}_{5} \times \mathrm{P}_{4}\left(-3.92^{* *}\right), \mathrm{P}_{5} \times \mathrm{P}_{1}\left(-3.83^{*}\right), \mathrm{P}_{5} \times \mathrm{P}_{2}\left(-3.45^{*}\right)$, and $\mathrm{P}_{6} \times \mathrm{P}_{2}\left(-1.42^{*}\right)$. The only one cross $\mathrm{P}_{4} \times \mathrm{P}_{3}$ showed the significant positive reciprocal effect $\left(1.69^{*}\right)$. Rest of the crosses had insignificant positive or negative effect. Negative significant reciprocal effect is desirable in this case because it provides opportunity for promoting early flowering in this crop (Table 4).

Table 4. Estimates of reciprocal effects in 15 crosses for days to flower and growth characters in bitter gourd.

\begin{tabular}{|c|c|c|c|c|c|c|c|}
\hline \multirow[b]{2}{*}{ Crosses } & \multicolumn{7}{|c|}{ Characters } \\
\hline & $\begin{array}{l}\text { Days to first } \\
\text { Male flower } \\
\text { opening }\end{array}$ & $\begin{array}{l}\text { Node } \\
\text { number of } \\
\text { first male } \\
\text { flower }\end{array}$ & $\begin{array}{c}\text { Days to } \\
\text { first female } \\
\text { flower } \\
\text { opening }\end{array}$ & $\begin{array}{c}\text { Node } \\
\text { number of } \\
\text { first female } \\
\text { flower }\end{array}$ & $\begin{array}{l}\text { Main vine } \\
\text { length (m) }\end{array}$ & $\begin{array}{c}\text { No. of } \\
\text { primary } \\
\text { branches } \\
\text { per vine }\end{array}$ & $\begin{array}{l}\text { No. of nodes } \\
\text { per main } \\
\text { vine (no.) }\end{array}$ \\
\hline $\mathrm{P}_{2} \mathrm{xP}_{1}$ & 1.33 & 1.50 & -1.11 & $-3.08^{* *}$ & 0.07 & -0.11 & -2.06 \\
\hline $\mathrm{P}_{3} \times \mathrm{P}_{1}$ & $-4.42^{* *}$ & 0.75 & $-4.00^{* *}$ & 0.86 & $0.43^{* *}$ & 0.28 & $7.81^{*}$ \\
\hline $\mathrm{P}_{4} \mathrm{XP}_{1}$ & 0.58 & 3.67 & 1.50 & $5.00^{* *}$ & 0.23 & $-0.45^{* *}$ & 4.04 \\
\hline $\mathrm{P}_{5} \mathrm{XP}_{1}$ & $-3.83^{* *}$ & 0.67 & -1.67 & 0.67 & -0.003 & $-0.55^{* *}$ & -0.36 \\
\hline $\mathrm{P}_{6} \mathrm{XP}_{1}$ & 0.14 & -0.47 & -1.58 & 1.08 & 0.16 & 0.42 & 0.96 \\
\hline $\mathrm{P}_{3} \mathrm{xP}_{2}$ & -0.92 & -0.75 & -0.33 & 1.17 & -0.27 & 0.31 & -1.75 \\
\hline $\mathrm{P}_{4} \mathrm{XP}_{2}$ & -0.75 & 0.25 & 0.67 & $2.00^{* *}$ & $0.39^{*}$ & -0.28 & 5.33 \\
\hline $\mathrm{P}_{5} \mathrm{XP}_{2}$ & $-3.45^{* *}$ & 1.28 & $-6-.61$ & -0.33 & $-0.66^{*}$ & -0.43 & 3.83 \\
\hline $\mathrm{P}_{6} \mathrm{XP}_{2}$ & $-1.42^{*}$ & 0.03 & -0.58 & 0.86 & 0.18 & -0.42 & -1.13 \\
\hline $\mathrm{P}_{4} \mathrm{XP}_{3}$ & $1.69^{*}$ & 0.06 & 1.11 & 0.00 & $0.37^{*}$ & -0.30 & 0.25 \\
\hline $\mathrm{P}_{5} \mathrm{xP}_{3}$ & -0.92 & -0.17 & $-2.69^{*}$ & -1.45 & $0.70^{* *}$ & 0.39 & $10.55^{* *}$ \\
\hline $\mathrm{P}_{6} \mathrm{XP}_{3}$ & 0.14 & -1.45 & $-3.83^{* *}$ & $-3.11^{* *}$ & -0.15 & -0.32 & -3.39 \\
\hline $\mathrm{P}_{5} \mathrm{XP}_{4}$ & $-3.92^{* *}$ & $-2.50^{* *}$ & $-4.92^{* *}$ & 0.50 & 0.11 & 0.15 & -4.08 \\
\hline $\mathrm{P}_{6} \mathrm{xP}_{4}$ & -1.50 & 1.33 & -1.53 & 0.58 & 0.06 & 0.08 & -0.50 \\
\hline $\mathrm{P}_{6} \times \mathrm{P}_{5}$ & 1.17 & 1.50 & -0.83 & 0.25 & 0.05 & 0.33 & 3.08 \\
\hline SE (rij) & 0.64 & 0.77 & 1.17 & 0.86 & 0.17 & 0.20 & 2.71 \\
\hline
\end{tabular}

${ }^{*}$ Significant at $5 \%$ level of probability; ${ }^{* *}$ Significant at $1 \%$ level of probability. Non-strike means non-significant up to $5 \%$ level of probability. 
Table 5. Estimates of reciprocal effects in 15 crosses for fruit yield and fruit characters in bitter gourd.

\begin{tabular}{|c|c|c|c|c|c|c|c|}
\hline \multirow[b]{2}{*}{ Crosses } & \multicolumn{7}{|c|}{ Characters } \\
\hline & $\begin{array}{l}\text { Number of } \\
\text { fruits per } \\
\text { vine (no.) }\end{array}$ & $\begin{array}{l}\text { Av. Single } \\
\text { fruit } \\
\text { weight(g) }\end{array}$ & $\begin{array}{l}\text { Fruit yield } \\
\text { per vine } \\
(\mathrm{kg})\end{array}$ & $\begin{array}{l}\text { Fruit length } \\
\qquad(\mathrm{cm})\end{array}$ & $\begin{array}{c}\text { Fruit } \\
\text { diameter } \\
(\mathrm{cm})\end{array}$ & $\begin{array}{l}\text { Thickness } \\
\text { of fruit } \\
\text { flesh (mm) }\end{array}$ & $\begin{array}{l}\text { Thickness } \\
\text { of fruit rind } \\
(\mathbf{m m})\end{array}$ \\
\hline $\mathrm{P}_{2} \mathrm{xP}_{1}$ & $-2.15^{* *}$ & $20.51^{* *}$ & $0.07^{*}$ & $1.50^{* *}$ & -0.03 & 0.25 & -0.28 \\
\hline $\mathrm{P}_{3} \mathrm{xP}_{1}$ & $2.42^{* *}$ & -4.18 & $0.27^{* *}$ & -0.86 & $0.63^{* *}$ & 0.84 & 0.21 \\
\hline $\mathrm{P}_{4} \mathrm{xP}_{1}$ & -0.46 & 5.46 & $0.10^{* *}$ & 0.37 & -0.16 & $-1.82^{*}$ & 0.05 \\
\hline $\mathrm{P}_{5} \mathrm{xP}_{1}$ & -0.36 & -0.58 & $-0.07^{*}$ & -1.23 & -0.21 & 0.95 & -0.02 \\
\hline $\mathrm{P}_{6} \mathrm{xP}_{1}$ & -0.42 & $13.61^{* *}$ & $0.13^{* *}$ & -1.20 & -0.27 & 0.41 & -0.19 \\
\hline $\mathrm{P}_{3} \mathrm{xP}_{2}$ & 0.75 & $-16.63^{* *}$ & -0.01 & -0.07 & $-0.33^{*}$ & $1.85^{*}$ & 0.20 \\
\hline $\mathrm{P}_{4} \mathrm{xP}_{2}$ & 0.00 & -0.54 & -0.002 & 1.94 & 0.08 & -0.83 & -0.09 \\
\hline $\mathrm{P}_{5} \mathrm{xP}_{2}$ & $-3.45^{* *}$ & 4.79 & $-0.23^{* *}$ & 0.37 & -0.08 & -0.86 & -0.22 \\
\hline $\mathrm{P}_{6} \mathrm{xP}_{2}$ & $-2.54^{* *}$ & 3.46 & $-0.32^{* *}$ & 1.04 & -0.05 & -0.39 & -0.14 \\
\hline $\mathrm{P}_{4} \mathrm{xP}_{3}$ & $-5.92^{* *}$ & $10.88^{* *}$ & $-0.23^{* *}$ & 0.70 & 0.10 & 1.33 & -0.44 \\
\hline $\mathrm{P}_{5} \mathrm{xP}_{3}$ & $1.56^{*}$ & -4.76 & $0.18^{* *}$ & $2.06^{* *}$ & -0.28 & $-2.49^{* *}$ & -0.49 \\
\hline $\mathrm{P}_{6} \mathrm{xP}_{3}$ & $1.78^{*}$ & $-18.61^{* *}$ & $-0.13^{* *}$ & 0.05 & 0.12 & 0.43 & 0.48 \\
\hline $\mathrm{P}_{5} \mathrm{xP}_{4}$ & $3.50^{* *}$ & $-20.46^{* *}$ & $0.13^{* *}$ & -0.03 & $-0.43^{* *}$ & $-3.16^{* *}$ & $-0.55^{* *}$ \\
\hline $\mathrm{P}_{6} \mathrm{xP}_{4}$ & $3.00^{* *}$ & $-7.53^{*}$ & $0.06^{*}$ & -1.73 & 0.06 & 1.06 & -0.25 \\
\hline $\mathrm{P}_{6} \mathrm{xP}_{5}$ & $1.67^{*}$ & $7.39 *$ & $-0.16^{* *}$ & -0.59 & 0.26 & 1.00 & 0.38 \\
\hline SE (rij) & 0.70 & 3.22 & 0.03 & 0.69 & 0.14 & 0.79 & 0.24 \\
\hline
\end{tabular}

${ }^{*}$ Significant at $5 \%$ level of probability; **Significant at $1 \%$ level of probability. Non-strike means non-significant up to $5 \%$ level of probability.

Table 6. Estimates of reciprocal effects in 15 crosses for days to maturity and seed characters in bitter gourd.

\begin{tabular}{|c|c|c|c|c|c|}
\hline \multirow[b]{2}{*}{ Crosses } & \multicolumn{5}{|c|}{ Character } \\
\hline & $\begin{array}{l}\text { Days to green } \\
\text { fruit maturity }\end{array}$ & $\begin{array}{c}\text { Days to seed fruit } \\
\text { maturity }\end{array}$ & $\begin{array}{c}\text { Number of seed } \\
\text { per fruit }\end{array}$ & $\begin{array}{l}\text { Seed weight per } \\
\text { fruit (g) }\end{array}$ & $\begin{array}{l}\text { 100-seed weight } \\
\text { (g) }\end{array}$ \\
\hline $\mathrm{P}_{2} \mathrm{xP}_{1}$ & -0.29 & $1.39^{*}$ & $7.43^{* *}$ & $1.02^{* *}$ & -0.16 \\
\hline $\mathrm{P}_{3} \mathrm{xP}_{1}$ & 0.17 & 0.39 & $2.07^{* *}$ & $0.55^{*}$ & 1.30 \\
\hline $\mathrm{P}_{4} \mathrm{XP}_{1}$ & $-1.42^{*}$ & -0.44 & $1.69^{* *}$ & 0.37 & 0.20 \\
\hline $\mathrm{P}_{5} \times \mathrm{P}_{1}$ & 0.80 & -0.33 & $1.34^{*}$ & 0.31 & 0.56 \\
\hline $\mathrm{P}_{6} \mathrm{XP}_{1}$ & 0.74 & -0.04 & $5.47^{* *}$ & 0.41 & $-2.68^{* *}$ \\
\hline $\mathrm{P}_{3} \mathrm{XP}_{2}$ & 0.18 & 1.11 & 0.75 & 0.28 & $1.22^{*}$ \\
\hline $\mathrm{P}_{4} \mathrm{XP}_{2}$ & 1.13 & 0.85 & $-1.29^{*}$ & -0.26 & -0.38 \\
\hline $\mathrm{P}_{5} \mathrm{XP}_{2}$ & -0.06 & $-1.66^{*}$ & $2.08^{* *}$ & $0.44^{*}$ & 0.25 \\
\hline $\mathrm{P}_{6} \mathrm{XP}_{2}$ & $2.37^{* *}$ & 0.12 & $-1.47^{* *}$ & -0.28 & -0.19 \\
\hline $\mathrm{P}_{4} \mathrm{XP}_{3}$ & -0.33 & 0.74 & 0.38 & 0.05 & -0.04 \\
\hline $\mathrm{P}_{5} \mathrm{xP}_{3}$ & $-1.52^{*}$ & -0.95 & $-4.64^{* *}$ & $-0.56^{*}$ & 0.61 \\
\hline $\mathrm{P}_{6} \mathrm{XP}_{3}$ & 0.34 & 0.17 & -0.59 & -0.26 & $-1.38^{* *}$ \\
\hline $\mathrm{P}_{5} \mathrm{XP}_{4}$ & 0.38 & $-1.37^{*}$ & $-2.75^{* *}$ & -0.19 & $1.67^{* *}$ \\
\hline $\mathrm{P}_{6} \mathrm{xP}_{4}$ & 0.48 & -0.70 & $4.49^{* *}$ & $0.92^{* *}$ & $1.18^{*}$ \\
\hline $\mathrm{P}_{6} \mathrm{xP}_{5}$ & 0.90 & -0.94 & -0.43 & $-0.50^{*}$ & $-2.67^{* *}$ \\
\hline SE(rij) & 0.62 & 0.48 & 0.55 & 0.20 & 0.45 \\
\hline
\end{tabular}

${ }^{*}$ Significant at $5 \%$ level of probability; ** Significant at $1 \%$ level of probability. Non-strike means non-significant up to $5 \%$ level of probability.

\subsection{Node number of first male flower}

All reciprocal crosses showed insignificant negative or positive reciprocal effect except one. The cross $\mathrm{P}_{5} \times \mathrm{P}_{4}$ showed significant and negative reciprocal value $\left(-3.92^{* *}\right)$, which was desirable for improving this character because it provided male flower in lower node. 


\subsection{Days to first female flower opening}

The cross combination $\mathrm{P}_{5} \times \mathrm{P}_{4}$ showed $\times$ highly significant and negative reciprocal value $\left(-4.92^{* *}\right)$ followed by $\mathrm{P}_{3} \mathrm{x}$ $\mathrm{P}_{1}\left(-4.00^{* *}\right), \mathrm{P}_{6} \times \mathrm{P}_{3}\left(-3.83^{* *}\right)$ and $\mathrm{P}_{5} \times \mathrm{P}_{3}\left(-2.69^{*}\right)$ for the character days to first female flower opening, other crosses had positive or negative reciprocal effects (Table 4). No cross had significant positive reciprocal effect. It was good for improving this trait. Early female flowering is desirable. So the crosses which had negative significant reciprocal effect were the best for improving this trait.

\subsection{Node number of first female flower}

Out of the 15 reciprocal crosses, only four showed significant reciprocal effects (two showed positive and two showed negative) (Table 4). The cross combinations, $\mathrm{P}_{4} \times \mathrm{P}_{1}\left(-3.11^{* *}\right), \mathrm{P}_{4} \times \mathrm{P}_{2}\left(2.00^{* *}\right)$ showed positive and $\mathrm{P}_{6} \times \mathrm{P}_{3}$ $\left(-3.11^{* *}\right)$ and $\mathrm{P}_{2} \times \mathrm{P}_{1}\left(-3.08^{* *}\right)$ showed negative reciprocal effect. Other crosses were insignificant. For improving this trait crosses $\mathrm{P}_{6} \times \mathrm{P}_{3}$ and $\mathrm{P}_{2} \times \mathrm{P}_{1}$ were the best because this two crosses provided female flower in lower node.

\subsection{Main vine length $(\mathrm{m})$}

The cross combination $\mathrm{P}_{5} \times \mathrm{P}_{3}$ exhibited maximum significant and positive reciprocal effect $\left(0.70^{* *}\right)$ followed by $\mathrm{P}_{3} \times \mathrm{P}_{1}\left(0.43^{* *}\right), \mathrm{P}_{4} \times \mathrm{P}_{2}\left(0.39^{*}\right)$ and $\left.\mathrm{P}_{4} \times \mathrm{P}_{3} 0.37^{* *}\right)$ (Table 4). Only one cross combination $\mathrm{P}_{5} \times \mathrm{P}_{2}$ showed negative reciprocal effect significantly. This indicates that this cross provides shorter vine length than their parents. Rest of the crosses had insignificant positive (seven) or negative (three) reciprocal value.

\subsection{Number of primary branches per vine}

Among the cross combinations only two crosses $\mathrm{P}_{5} \times \mathrm{P}_{1}$ $\left(-0.55^{* *}\right)$ and $\mathrm{P}_{4} \times \mathrm{P}_{1}\left(-0.45^{* *}\right)$ were negatively significant for reciprocal effects of number for primary branches per vine. Other crosses had positive or negative insignificant Reciprocal value.

\subsection{Number of nodes per main vine (no.)}

The highest significant positive value of reciprocal effects for this character were manifested by $\mathrm{P}_{5} \times \mathrm{P}_{3}\left(10.55^{* *}\right)$ followed by $\mathrm{P}_{3} \times \mathrm{P}_{1}\left(7.81^{*}\right)$ (Table 4$)$. Rest of the crosses was positively or negatively insignificant. Hence, the cross combination $\mathrm{P}_{5} \times \mathrm{P}_{3}$ was the best reciprocal combination to enhance the nodes on main vine.

\subsection{Number of fruits per vine (no.)}

Among the cross combinations, $\mathrm{P}_{5} \times \mathrm{P}_{4}\left(3.50^{* *}\right)$ showed the highest significant and positive reciprocal effect followed by $\mathrm{P}_{6} \times \mathrm{P}_{4}\left(3.00^{*}\right), \mathrm{P}_{3} \times \mathrm{P}_{1}\left(2.42^{* *}\right), \mathrm{P}_{6} \times \mathrm{P}_{3}\left(1.78^{*}\right)$, $\mathrm{P}_{6} \times \mathrm{P}_{5}\left(1.67^{* *}\right)$, and $\mathrm{P}_{5} \times \mathrm{P}_{3}\left(1.56^{*}\right)$. On the other hand the cross $\mathrm{P}_{4} \times \mathrm{P}_{3}\left(-5.92^{* *}\right)$ had the highest significant negative reciprocal effect followed by $\mathrm{P}_{5} \times \mathrm{P}_{2}\left(-3.45^{* *}\right)$ and $\mathrm{P}_{6} \times \mathrm{P}_{2}$ $\left(-2.54^{* *}\right)$. Rest of the five crosses had insignificant positive or negative reciprocal value (Table 5 ). Thus the reciprocal cross combination $\mathrm{P}_{5} \times \mathrm{P}_{4}$ was the best combination to increase the number of fruits per vine followed by $\mathrm{P}_{6} \mathrm{x}$ $\mathrm{P}_{4}$ and $\mathrm{P}_{3} \times \mathrm{P}_{1}$.

\subsection{Average single fruit weight $(g)$}

Out of the 15 reciprocal cross combinations the crosses $\mathrm{P}_{2} \times \mathrm{P}_{1}\left(20.51^{* *}\right)$ exhibited the highest significant and positive reciprocal effects for average single fruit weight followed by $\mathrm{P}_{6} \times \mathrm{P}_{1}\left(13.61^{* *}\right), \mathrm{P}_{4} \times \mathrm{P}_{3}\left(10.88^{* *}\right)$, and $\mathrm{P}_{6} \times \mathrm{P}_{5}$ $\left(4.39^{*}\right)$. On the other hand, the cross $\mathrm{P}_{5} \times \mathrm{P}_{4}$ showed the highest significant but negative Rec. effects $\left(-20.46^{* *}\right)$ followed by $\mathrm{P}_{6} \times \mathrm{P}_{3}\left(-18.61^{* *}\right), \mathrm{P}_{3} \times \mathrm{P}_{2}\left(-16.33^{* *}\right)$ and $\mathrm{P}_{6}$ $\mathrm{x} \mathrm{P}_{4}\left(-7.55^{*}\right)$ (Table 5). The F1 of $\mathrm{P}_{2} \times \mathrm{P}_{1}$ was the best for maximum weighted fruit and $\mathrm{P} 4 \mathrm{xP}_{3}$ was the best reciprocal combination for moderate weighted fruit.

\subsection{Fruit yield per vine $(\mathrm{kg})$}

Among the cross combinations, $\mathrm{P}_{3} \times \mathrm{P}_{1}\left(0.27^{* *}\right)$ exhibited the highest significant and positive reciprocal effects for this trait followed by $\mathrm{P}_{5} \times \mathrm{P}_{3}, \mathrm{P}_{6} \times \mathrm{P}_{1}$ and $\mathrm{P}_{5} \times \mathrm{P}_{4}$ (Table 5). On the other side, the cross $P_{6} \times P_{2}(-0.32)$ showed the highest but negative reciprocal effect followed by $\mathrm{P}_{4} \times \mathrm{P}_{3}$, $\mathrm{P}_{5} \times \mathrm{P}_{2}$ and $\mathrm{P}_{6} \times \mathrm{P}_{3}$. Hence, $\mathrm{P}_{3} \times \mathrm{P}_{1}$ was the best for reciprocal combinations for increasing the fruit yield per vine.

\subsection{Fruit length $(\mathrm{cm})$}

Most of reciprocal crosses showed insignificant positive or negative reciprocal effects. Only two crosses $\mathrm{P}_{2} \times \mathrm{P}_{1}$ and $\mathrm{P}_{5} \times \mathrm{P}_{3}$ exhibited the positively significant reciprocal effects for this character. Thus, the cross combination $\mathrm{P}_{2}$ $x P_{1}$ was the best for reciprocal combination to increase the fruit length in this crop.

\subsection{Fruit diameter ( $\mathrm{cm}$ )}

Only three crosses provided significant (one was positive and two was negative) reciprocal effects (Table 5). Other crosses had positive or negative insignificant reciprocal value. Considering the findings of the character, cross $P_{5}$ $\mathrm{x} \mathrm{P}_{4}$ was the best for reducing the diameter of the fruit in this crop.

\subsection{Thickness of the fruit flesh ( $\mathrm{mm}$ )}

The cross combination $\mathrm{P}_{5} \times \mathrm{P}_{4}, \mathrm{P}_{5} \times \mathrm{P}_{3}$, and $\mathrm{P}_{4} \times \mathrm{P}_{1}$ exhibited significant and negative reciprocal effects of which $\mathrm{P}_{5} \mathrm{x}_{4}$ provided the maximum negative value $\left(-3.16^{* *}\right)$ for the parameter thickness of the fruit flesh (Table 5). Only one reciprocal cross $\mathrm{P}_{3} \times \mathrm{P}_{2}\left(1.85^{*}\right)$ showed significant and positive reciprocal effect (Table 5). Hence, the $\mathrm{P}_{5} \times \mathrm{P}_{4}$ was the best reciprocal cross for reducing the thickness of the fruit flesh which is desirable.

\subsection{Thickness of fruit rind ( $\mathrm{mm}$ )}

All of the reciprocal crosses were insignificant except one, which was $\mathrm{P}_{5} \times \mathrm{P}_{4}$ but had negative value $\left(-0.55^{* *}\right)$, is not desirable. So there was no chance for improving the thickness of the fruit rind effectively.

\subsection{Days to green fruit maturity}

The cross combination $\mathrm{P}_{6} \times \mathrm{P}_{2}$ showed the highest significant and positive reciprocal effect $\left(2.37^{* *}\right)$, while significant and negative value for this trait was obtained from $\mathrm{P}_{5} \times \mathrm{P}_{3}\left(-1.52^{*}\right)$ and $\mathrm{P}_{4} \times \mathrm{P}_{1}\left(-1.42^{*}\right)$. Rest twelve crosses 
had insignificant positive or negative reciprocal value. Hence, the cross combination $\mathrm{P}_{5} \times \mathrm{P}_{3}$ and $\mathrm{P}_{4} \times \mathrm{P}_{1}$ provided opportunity for early maturing in this crop (Table 6).

\subsection{Days to seed fruit maturity}

Only one cross $\mathrm{P}_{2} \times \mathrm{P}_{1}\left(1.39^{*}\right)$ showed positive significant reciprocal effect for days to seed fruit maturity. On the other hand two crosses $\mathrm{P}_{5} \times \mathrm{P}_{2}\left(-1.66^{*}\right)$ and $\mathrm{P}_{5} \times \mathrm{P}_{4}\left(-1.37^{*}\right)$ exhibited negatively significant reciprocal effect. Other crosses were insignificant positive or negative reciprocal effect. Thus the reciprocal cross combination $\mathrm{P}_{5} \times \mathrm{P}_{2}$ and $\mathrm{P}_{5} \times \mathrm{P}_{4}$ provides opportunity for early seed fruit maturity in this crop (Table 6).

\subsection{Number of seed per fruit}

Highest significant and positive Rec. effects was observed in the combination $\mathrm{P}_{2} \times \mathrm{P}_{1}\left(7.43^{* *}\right)$ followed by $\mathrm{P}_{6} \times \mathrm{P}_{4}$ (4.49**), $\mathrm{P}_{5} \times \mathrm{P}_{2}\left(2.08^{* *}\right)$, and $\mathrm{P}_{3} \times \mathrm{P}_{1}\left(2.07^{* *}\right)$. Whereas the highest negatively significant reciprocal effect $\left(-4.46^{* *}\right)$ was obtained by the cross $\mathrm{P}_{5} \times \mathrm{P}_{3}$, which was followed by $\mathrm{P}_{5} \times \mathrm{P}_{4}\left(-2.75^{* *}\right)$ and $\mathrm{P}_{6} \times \mathrm{P}_{2}\left(-1.47^{* *}\right)$. So, reciprocal cross $\mathrm{P}_{5} \times \mathrm{P}_{3}$ considered the best reciprocal cross combination for less seeded type fruit development in this crop as less seeded type fruit is more preferable (Table 6)

\subsection{Seed weight per fruit ( $g$ )}

In Table 5 the cross combination $\mathrm{P}_{2} \times \mathrm{P}_{1}\left(1.02^{* *}\right)$ provided maximum reciprocal value of the parameter followed by $\mathrm{P}_{6} \times \mathrm{P}_{4}, \mathrm{P}_{3} \times \mathrm{P}_{1}$ and $\mathrm{P}_{5} \times \mathrm{P}_{2}$. But the cross $\mathrm{P}_{5} \times \mathrm{P}_{3}\left(-0.56^{*}\right)$ showed the negatively highest significant reciprocal effect followed by $\mathrm{P}_{6} \times \mathrm{P}_{5}\left(-0.50^{*}\right)$. Remaining cross combinations showed non-significant positive or negative reciprocal effects. Thus the reciprocal cross combination $\mathrm{P}_{5} \times \mathrm{P}_{3}$ and $\mathrm{P}_{6} \times \mathrm{P}_{5}$ were superior considering the small seeded type fruit development.

\subsection{0-seed weight ( $g$ )}

The reciprocal cross combination $\mathrm{P}_{5} \times \mathrm{P}_{4}$ indicated the maximum reciprocal effect $\left(1.67^{*}\right)$, which was followed by $\mathrm{P}_{6} \times \mathrm{P}_{4}\left(1.18^{*}\right)$ and $\mathrm{P}_{3} \times \mathrm{P}_{2}\left(1.22^{*}\right)$. On the other hand the cross combination $\mathrm{P}_{6} \times \mathrm{P}_{1}$ provided the maximum significant but negative reciprocal effect $\left(-2.68^{* *}\right)$ followed by $\mathrm{P}_{6} \times \mathrm{P}_{5}\left(-2.67^{* *}\right)$ and $\mathrm{P}_{6} \times \mathrm{P}_{3}\left(-1.38^{* *}\right)$. Rest reciprocal cross combinations were non-significant (Table 6). Hence, the reciprocal cross combinations $\mathrm{P}_{6} \times \mathrm{P}_{1} \mathrm{P}_{6} \times \mathrm{P}_{5}$ and $\mathrm{P}_{6} \mathrm{x}$ $\mathrm{P}_{3}$ were the better for developing fruit which contained lesser weight of seed.

Considering the reciprocal effect of the all 19 characters studied, it may be said that characters having significant reciprocal effect indicated the controlled genes also present in the cytoplasm. Earlier, similar type of result was reported by Khan et al. (2016) in snake gourd. Shukla et al. (2014b) reported significant reciprocal effect for seeds per fruit and 100 -seed weight in bitter gourd. Similar findings were also reported by Nyadanu et al. (2017) in brinjal.

\section{Conclusions}

Combining ability studies involving $6 \times 6$ full diallel crosses indicated both additive and non-additive gene action in the expression of different characters. Additive gene action was found to be predominant. The genotype BG 009 was the best general combiner for promoting earliness. Genotype BG 006 was good for promoting earliness as well as most other important characters, namely, number of fruits per vine, average single fruit weight and fruit yield per vine. BG 027 was the best for female flower at lower node. BG 036 was best for main vine length, number of primary branches per vine and number of nodes per main vine. Significant SCA effects were displayed for early female flowering in crosses $\mathrm{P}_{1} \mathrm{XP}_{2}$ and $\mathrm{P}_{3} \mathrm{XP}_{5}$; fruits per vine in $\mathrm{P}_{2} \mathrm{xP}_{4}, \mathrm{P}_{4} \mathrm{xP}_{6}, \mathrm{P}_{2} \mathrm{xP}_{5}$ and $\mathrm{P}_{3} \mathrm{xP}_{5}$; average single fruit weight in $\mathrm{P}_{1} \mathrm{xP}_{3}, \mathrm{P}_{3} \mathrm{xP}_{5}, \mathrm{P}_{2} \mathrm{xP}_{3}$ and $\mathrm{P}_{1} \mathrm{xP}_{5}$. So, these are the important specific combinations which may be used for the improvement of the respective characters. Significant reciprocal effects were also observed in most important traits namely, days to first male and female flower (which is very desirable), number of fruits per vine, average fruit weight and fruit yield. Reciprocal crosses can be utilized for improvement of the desired traits.

\section{Acknowledgements}

The authors are sincerely acknowledge to Bangladesh Agricultural Research Institute (BARI) and Faculty of Sustainable Agriculture, Universiti Malaysia Sabah for all the support and facilities to conduct this experiment and the initiatives to publish the research findings.

\section{References}

ALAM, M.A., UDDIN, R., SUBHAN, N., RAHMAN, M.M., JAIN, P. and REZA, H.M., 2015. Beneficial role of Bitter melon supplementation in obesity and related complications in metabolic syndrome. Journal of Lipids, vol. 2015, pp. 1-18. http:// dx.doi.org/10.1155/2015/496169. PMid:25650336.

AHSAN, F.N., ISLAM, A.K.M.A., RASUL, M.G., MIAN, M.A.K. and HOSSAIN, M.M., 2011. Preliminary studies on heterosis in Snakegourd (Triconsanthes cucumerina). Vegetable Crops Research Bulletin, vol. 74, pp. 25-38. http://dx.doi.org/10.2478/ v10032-011-0002-X.

BAHARI, M., RAFII, M.Y., SALEH, G.B. and LATIF, M.A., 2012. Combining ability analysis in complete diallel cross of watermelon (Citrullus lanatus (Thunb.) Matsum. \& Nakai). The Scientifi cWorld Journal, vol. 2012, pp. 543158. http://dx.doi.org/10.1100/2012/543158. PMid:22566772.

BALAT, J.R., PATEL, J.B., DELVADIYA, I.R. and GINOYA, A.V., 2021. Combining ability studies for fruit yield and its components in Bottle gourd [Lagenaria siceraria (Mol.) Standl.]. Biological Forum - International Journal, vol. 13, no. 2, pp. 396-403.

BEGNA, T., 2021. Role and economic importance of crop genetic diversity in food security. International Journal of Agricultural Science and Food Technology, vol. 7, no. 1, pp. 164-169.

BEHERA, T.K., DEY, S.S., DATTA, S. and KOLE, C., 2020. Classical genetics and traditional breeding. In: C. KOLE, H. MATSUMURA and T. BEHERA, eds. The Bitter gourd genome: compendium of 
plant genomes. Switzerland: Springer, pp. 45-59. http://dx.doi. org/10.1007/978-3-030-15062-4_4.

DEVI, N.D., MARIAPPAN, S.T., ARUMUGAM, T., MOHAN, S. and ANANDAKUMAR, C.R., 2017a. Combining ability and heterosis in snake Gourd (Trichosanthes cucumerina L.). Madras Agricultural Journal, vol. 104, no. 10-12, pp. 410-414. http:// dx.doi.org/10.29321/MAJ.2017.000089.

DEVI, N.D., MARIAPPAN, S., ARUMUGAM, T. and ANANDAKUMAR, C.R., 2017b. Estimating combining ability for yield and yield contributing traits in Snake gourd (Trichosanthes cucumerina L.). International Journal of Current Microbiology and Applied Sciences, vol. 6, no. 2, pp. 795-800. http://dx.doi.org/10.20546/ ijcmas.2017.602.088.

DEVMORE, J.P., BHAVE, S.G., BURONDKAR, M.M., DHEKALE, J.S. and SAWARDEKAR, S.V., 2016. Genetic analysis for fruit yield and its component traits in brinjal (Solanum melongena L.). Electronic Journal of Plant Breeding, vol. 7, no. 4, pp. 1040-1045. http:// dx.doi.org/10.5958/0975-928X.2016.00142.3.

FASAHAT, P., RAJABI, A., RAD, J.M. and DERERA, J., 2016. Principles and utilization of combining ability in plant breeding. Biometrics E'Biostatistics International Journal, vol. 4, no. 1, pp. 1-22. http:// dx.doi.org/10.15406/bbij.2016.04.00085.

GOLABADI, M., GOLKAR, P. and ERCISLI, S., 2017. Estimation of gene action for fruit yield and morphological traits in greenhouse cucumber by mating designs. Acta Scientiarum Polonorum. Hortorum Cultus, vol. 16, no. 4, pp. 3-12. http:// dx.doi.org/10.24326/asphc.2017.4.1.

GRIFFING, B., 1956. A generalized treatment of the use of diallel cross in quantitative inheritance. Heridity, vol. 10, no. 1, pp. 31-50. http://dx.doi.org/10.1038/hdy.1956.2.

JASIM, E.A.A. and ESHO, K.B., 2021. Study the line x tester hybridization, [ii] seeds yield and it's component in Squash (Cucurbita pepo L.). Plant Archives, vol. 21, no. 1, suppl., pp. 1-5. http://dx.doi.org/10.51470/PLANTARCHIVES.2021.v21.S1.001.

KANITI, K.R., 2016. Combining ability for yield related traits, earliness and yield in Bitter gourd (Momordica charantia L.). Electronic Journal of Plant Breeding, vol. 7, no. 2, pp. 267-270. http://dx.doi.org/10.5958/0975-928X.2016.00034.X.

KHAN, A.S.M.M.R., EYASMIN, R., RASHID, M.H., ISHTIAQUE, S. and CHAKI, A.K., 2016. Variability, heritability, character association, path analysis and morphological diversity in snake gourd. Agriculture and Natural Resources (Bangkok), vol. 50, no. 6, pp. 483-489. http://dx.doi.org/10.1016/j.anres.2016.07.005.

LABROO, M.R., STUDER, A.J. and RUTKOSKI, J.E., 2021. Heterosis and hybrid crop breeding: a multidisciplinary review. Frontiers in Genetics, vol. 12, pp. 643761. http://dx.doi.org/10.3389/ fgene.2021.643761. PMid:33719351.

MALVE, G.M., JAGTAP, V.S. and KATE, P.A., 2021. Studies on combining ability in bitter gourd (Momordica charantia L.). The Pharma Innovation Journal, vol. 10, no. 1, pp. 147-150.

MISHRA, V. and SINGH, D.K., 2018. Combining ability and heterosis studies in Bitter guard (Momordica charactia L.). International Journal of Current Microbiology and Applied Sciences, vol. 7, no. 7, pp. 4278-4289. http://dx.doi.org/10.20546/ijcmas.2018.707.499.

NAPOLITANO, M., TERZAROLI, N., KASHYAP, S., RUSSI, L., JONESEVANS, E. and ALBERTINI, E., 2020. Exploring Heterosis in Melon (Cucumis melo L.). Plants, vol. 9, no. 2, pp. 1-19. http://dx.doi. org/10.3390/plants9020282. PMid:32098173.

NASREEN, S., AHMED, R. and UDDIN, M.N., 2013. Requirement of N, $\mathrm{P}, \mathrm{K}$, and $\mathrm{S}$ for yield maximization of Bitter gourd (Momordica charantia). Bangladesh Journal of Agricultural Research, vol. 38 , no. 2, pp. 355-361. http://dx.doi.org/10.3329/bjar.v38i2.15896.
NYADANU, D., ADU-AMOAH, R., KWARTENG, A.O., AKROMAH, R., ABOAGYE, L.M., ADU-DAPAAH, H., DAGADU, F.K., KYIRIKA, D., JOTI, K.G. and OPPONG, G., 2017. Combining ability and genetic analysis of fruit and leaf yield in Gboma eggplant. African Crop Science Journal, vol. 25, no. 1, pp. 97-107. http://dx.doi. org/10.4314/acsj.v25i1.7.

PODDER, R., RASUL, M.G., ISLAM, A.K.M.A., MIAN, M.A.K. and AHMED, J.U., 2010. Combining ability and heterosis in Snakegourd (Tricosanthes cucurminata L). Bangladesh Journal of Plant Breeding and Genetics, vol. 23, no. 2, pp. 1-6. http:// dx.doi.org/10.3329/bjpbg.v23i2.9318.

QUAMRUZZAMAN, A., RASHID, M.A., MASUD, M.A.T. and UDDIN, M.N., 2009. Heterosis in Bottle gourd. Bangladesh Journal of Agricultural Research, vol. 34, no. 3, pp. 465-472. http://dx.doi. org/10.3329/bjar.v34i3.3973.

QUAMRUZZAMAN, A., SALIM, M.M.R., AKHTER, L., RAHMAN, M.M. and CHOWDHURY, M.A.Z., 2020. Gene action for yield contributing character in Bottle Gourd. European Journal of Agriculture and Food Sciences, vol. 2, no. 3, pp. 1-8. http://dx.doi. org/10.24018/ejfood.2020.2.3.51.

RAJKUMAR, M., KARUPPAIAH, P., SURESHKUMAR, R., SENDHILNATHAN, R. and KUMAR, N.S., 2019. Graphical analysis of fruit yield and its component characters in snake gourd (Trichosanthes anguina L.). Plant Archives, vol. 19, no. 2, pp. 2925-2928.

RANI, K.U. and REDDY, E.N., 2017. Combining Ability Analysis for Yield and its Components in Bottle Gourd. International Journal of Pure and Applied Bioscience, vol. 5, no. 4, pp. 809-817. http:// dx.doi.org/10.18782/2320-7051.5401.

ROSE, B., YADAV, F., PARIDA, P. and HASEENA, K., 2014. Study of wild bitter melon species in different geographical area. Journal of Ethnopharmacology, vol. 97, no. 6, pp. 156-167.

SHUKLA, A., RAI, A.K., BHARADWAJ, D.R., SINGH, U. and SINGH, M., 2014a. Combining ability analysis in bitter gourd using gynoecious lines. Vegetable Science, vol. 41, no. 2, pp. 180-183.

SHUKLA, A., SINGH, U., RAI, A.K., BHARADWAJ, D.R. and SINGH, M., 2014b. Genetic analysis of yield and yield attributing traits in bitter gourd. Vegetable Science, vol. 41, no. 1, pp. 37-41.

SINGH, A.K., PAN, R.S. and BHAVANA, P., 2013. Heterosis and combining ability analysis in Bittergourd (Momordica charantia L.). The Bioscan, vol. 8, no. 4, pp. 1533-1536.

TALUKDER, Z.H., KHAN, M.H., DAS, A.K. and UDDIN, N., 2018. Assessment of genetic variability, heritability and genetic advance in bitter gourd (Momordica charantia $\mathrm{L}$ ) for yield and yield contributing traits in Bangladesh. Scholar Journal of Applied Sciences and Research, vol. 1, no. 6, pp. 9-18.

THANGAMANI, C., PUGALENDHI, L., SUMATHI, T., KAVITHA, C. and RAJASHREE, V., 2011. Estimation of combining ability and heterosis for yield and quality characters in bitter gourd (Momordica charantia L.). Electronic Journal of Plant Breeding, vol. 2, no. 1, pp. 62-66.

VALYAIE, A., AZIZI, M., KASHI, A., SATHASIVAM, R., PARK, S.U., SUGIYAMA, A., MOTOBAYASHI, T. and FUJII, Y., 2021. Evaluation of growth, yield, and biochemical attributes of bitter gourd (Momordica charantia L.) cultivars under Karaj conditions in Iran. Plants, vol. 10, no. 7, pp. 1-19. http://dx.doi.org/10.3390/ plants10071370. PMid:34371573.

ZONGO, A., KONATE, A.K., KOÏTA, K., SAWADOGO, M., SANKARA, P., NTARE, B.R. and DESMAE, H., 2019. Diallel analysis of early leaf spot (Cercospora arachidicola Hori) disease resistance in groundnut. Agronomy, vol. 9, no. 1, pp. 15. http://dx.doi. org/10.3390/agronomy9010015. PMid:33304639. 